Article

\title{
Curcuma aromatica and Curcuma comosa Extracts and Isolated Constituents Provide Protection against UVB-Induced Damage and Attenuate Matrix Metalloproteinase-1 Expression in HaCaT Cells
}

\author{
Wachirachai Pabuprapap ${ }^{1}\left(\mathbb{D}\right.$, Wongnapa Nakyai ${ }^{1, *}$, Waraluck Chaichompoo ${ }^{1} \mathbb{D}$, Nattharika Pheedee ${ }^{1}$, \\ Saowanee Phetkeereerat ${ }^{1}$, Jarupa Viyoch ${ }^{2}$, Boon-ek Yingyongnarongkul ${ }^{1}$, Vachiraporn Ajavakom ${ }^{1}$, \\ Apiwat Chompoosor ${ }^{1}$, Pawinee Piyachaturawat ${ }^{3}$ and Apichart Suksamrarn ${ }^{1}$
}

check for

updates

Citation: Pabuprapap, W.;

Nakyai, W.; Chaichompoo, W.; Pheedee, N.; Phetkeereerat, S.; Viyoch, J.; Yingyongnarongkul, B.-e.; Ajavakom, V.; Chompoosor, A.; Piyachaturawat, P.; et al. Curcuma aromatica and Curcuma comosa Extracts and Isolated Constituents Provide Protection against UVB-Induced Damage and Attenuate Matrix Metalloproteinase-1

Expression in HaCaT Cells. Cosmetics 2022, 9, 23. https://doi.org/10.3390/ cosmetics 9010023

Academic Editor: Piera Di Martino

Received: 11 January 2022

Accepted: 8 February 2022

Published: 11 February 2022

Publisher's Note: MDPI stays neutral with regard to jurisdictional claims in published maps and institutional affiliations.

Copyright: (C) 2022 by the authors. Licensee MDPI, Basel, Switzerland. This article is an open access article distributed under the terms and conditions of the Creative Commons Attribution (CC BY) license (https:// creativecommons.org/licenses/by/ $4.0 /)$.
1 Department of Chemistry and Center of Excellence for Innovation in Chemistry, Faculty of Science, Ramkhamhaeng University, Bangkok 10240, Thailand; wachirachai7@gmail.com (W.P.); waraluck_kik@hotmail.com (W.C.); nattharika.1315@gmail.com (N.P.); saowan6841@gmail.com (S.P.); boon-ek.y@rumail.ru.ac.th (B.-e.Y.); vachiraporn.a@rumail.ru.ac.th (V.A.); apiwat.c@rumail.ru.ac.th (A.C.); s_apichart@ru.ac.th (A.S.)

2 Department of Pharmaceutical Technology and Center of Excellence for Innovation in Chemistry, Faculty of Pharmaceutical Sciences, Naresuan University, Phitsanulok 65000, Thailand; jarupav@nu.ac.th

3 Department of Physiology, Faculty of Science, Mahidol University, Bangkok 10400, Thailand; pawinee.pia@mahidol.ac.th

* Correspondence: wongnapa_n@rumail.ru.ac.th or wongnapanakyai@hotmail.co.th; Tel.: +66-2310-8400

\begin{abstract}
Ultraviolet-B (UVB) exposure is one of the primary extrinsic factors causing skin photoaging. It stimulates inflammatory responses and arrests the cell cycle. Matrix metalloproteinase-1 (MMP-1) secreted by keratinocytes is one of the important extracellular matrixes to attenuate UVB-induced skin aging via collagen degradation. Curcuma aromatica (CA) and Curcuma comosa (CC), the herbaceous plants in the Zingiberaceae family, are commonly used in Thai traditional women's medicines. The present work was aimed to investigate the potential of the CA and CC extracts and their isolated compounds to attenuate UVB-induced MMP-1 and cell cycle arrest in HaCaT keratinocytes. Total phenolic contents and antioxidant capacities of the extracts were determined. CC extract contains more phenolic components and provides more potent antioxidant activities than CA extract. HaCaTs were pretreated with the extracts or their isolated constituents 1-4 for $24 \mathrm{~h}$ and then repeatedly exposed to UVB at $100 \mathrm{~mJ} / \mathrm{cm}^{2} 10$ times. Both extracts and compounds 1-4 effectively reduce UVBinduced MMP-1 levels in HaCaT cells and restore cell cycle arrest. This is the first report on the potential of CA and CC extracts in reducing UVB-induced MMP-1 expression and regulating cell proliferation in $\mathrm{HaCaT}$ cells. Thus, $\mathrm{CA}$ and $\mathrm{CC}$ extracts might be used as alternative natural agents to prevent UVB-induced skin photoaging.
\end{abstract}

Keywords: Curcuma aromatica; Curcuma comosa; Zingiberaceae; sesquiterpenoids; diarylheptanoids; ultraviolet-B; matrix metalloproteinase-1; skin photoaging

\section{Introduction}

Skin aging is a complicated biological process affected by both intrinsic and extrinsic influences. Intrinsic factors for example genetics, cellular metabolism, hormone, and metabolic processes, are considered to be the root cause of skin aging. Up to the age of 50 , intrinsic changes occurred in people aged skin represents generalized atrophy with minimal structural changes resulting in slow deterioration. In contrast, UV exposure, one of the most well-known extrinsic factors, may influentially cause the physical damage to the skin responsible for skin photoaging [1-4]. The three types of UV radiation including UVA (320-400 nm), UVB (290-320 nm) and UVC (100-290 nm) can be harmful to human 
beings. However, the latter group does not reach the skin, since it is filtered by atmospheric ozone [5]. Although long-wavelength UVA radiation is considered to penetrate the skin reaching the deeper dermal layers, short-wavelength UVB exposure with more energy radiation is principally absorbed by the epidermis layer, which contains the most abundant keratinocyte cells [6,7]. UVB is responsible for the majority of UV radiation that directly penetrates the skin, which causes skin pigmentation and wrinkles, as well as inducing the synthesis of activator protein-1 (AP-1), activating nuclear factor kappa-light-chainenhancer of activated B cells (NF-kB), generating reactive oxygen species (ROS) on cell surface receptors, such mitogen-activated kinases (MAPK) stimulating the induction and also the expression of matrix metalloproteinases (MMPs) [8]. Thus, because of this damage it is well-established that UVB is more genotoxic than UVA. Matrix metalloproteinases, a family of matrix metallopeptidases or calcium-dependent zinc-containing endopeptidases, degrade proteins and enzymes in the extracellular matrix (ECM) $[9,10]$. MMP-1, commonly known as a rate-limiting collagenase, is an enzyme that breaks down collagen, the most common protein in dermal connective tissue. Collagen breakdown and degradation are hallmarks of photoaging, so an increase in MMP-1 expression or activity is an indication of UV-induced skin damage [11-14].

Curcuma aromatica Salisb. (CA) belongs to the Zingiberaceae family, which is widely distributed in China, Japan, and southeastern Asia [15]. The rhizomes of CA are commonly used in oriental traditional medicines for tonic, carminative purposes, and externally in combinations with astringents, bitters, aromatics to treat bruises, skin eruptions, and infections, and to improve complexion, promoting blood circulation to eliminate blood stasis [16]. They have also been reported to possess various pharmacological activities including wound healing, anti-microbial, anti-angiogenic, anthelmintic, anti-tumor, cytoprotective, anti-inflammatory and antioxidant activities [17]. The extract of the rhizome of CA has been found to contain sesquiterpenoids and diterpenoids [18,19]. Curcuma comosa Roxb. (CC) is a phytoestrogen-producing plant belonging to the Zingiberaceae family [20]. The rhizomes of CC have been used to treat flatulence and gynecologic diseases, such as premenstrual syndrome, irregular menstruation, and uterine discomfort. In Southeast Asia, this plant is used as an active ingredient in a variety of traditional women's medicines. It possesses estrogenic-like properties and is commonly used by postmenopausal women [21-23]. Previous phytochemical investigations of this plant revealed the presence of a rich source of diarylheptanoids [24]. Moreover, it has also been reported for various pharmacological activities including lipid-lowering, anti-adipogenic, bone sparing in ovariectomized rats, enhancing the expansion of hematopoietic stem cells for treatment of hematological disorders, antioxidant and anti-inflammatory activities [25-31].

Although CA and CC are known to possess several biological activities, the knowledge of their skin anti-aging potentials is still ambiguous and no previous studies have been performed to investigate the ability of CA and CC extracts to preserve against UVBinduced human HaCaT cells. Therefore, the present study of the effect of CA and CC extracts together with their isolated constituents on UVB-induced MMP-1 expression, cell proliferation and cell cycle profile in $\mathrm{HaCaT}$ cells can be potentially beneficial to the application for skin anti-aging products.

\section{Materials and Methods}

\subsection{Reagents and Chemicals}

All chemicals and solvents were used as received from Merck (Darmstadt, Germany), TCI (Tokyo, Japan), or Sigma-Aldrich (St. Louis, MO, USA). 3-(4,5-Dimethylthiazol-2-yl)-5(3-carboxymethoxyphenyl)-2-(4-sulfophenyl)-2H-tetrazolium (MTS) (Abcam, Cambridge, MA, USA), Dulbecco's Modified Eagle's Medium (DMEM) (Gibco, Waltham, MA, USA), Penicillin-Streptomycin (Gibco, Waltham, MA, USA), Amphotericin B (Gibco, Waltham, MA, USA), Trypsin-EDTA (Gibco, Waltham, MA, USA), Fetal Bovine Serum (FBS) (Gibco, Waltham, MA, USA), Matrix Metalloproteinase-1 (MMP-1) Human ELISA kit (Abcam, Cambridge, MA, USA) and Muse ${ }^{\circledR}$ Cell Cycle kit (Merck Millipore, Darmstadt, Germany) 
were used. The extraction and isolation solvents were analytical grade and the HPLC mobile phases were HPLC grade.

\subsection{Plant Materials}

The rhizomes of Curcuma aromatica were collected from Sawang Daen Din district, Sakon Nakhon Province, Thailand, and the rhizomes of Curcuma comosa were collected from Kamphaeng Saen district, Nakhon Pathom Province, Thailand in January 2020. The plant species were identified by Assoc. Prof. Nopporn Dumrongsiri, Ramkhamhaeng University. The voucher specimens are deposited at the Faculty of Science, Ramkhamhaeng University, Thailand (Apichart Suksamrarn, Nos. 095 and 099, respectively).

\subsection{Preparation of Plant Extracts}

The fresh rhizomes of $C$. aromatica and C. comosa were separately sliced, air-dried, milled, and macerated with $95 \%(v / v)$ ethanol at room temperature for $72 \mathrm{~h}$. The extraction procedure for each of the plant materials was repeated five times. The combined solution was filtered and the solvent was evaporated in vacuo at $40-45{ }^{\circ} \mathrm{C}$. The residues were freeze-dried to remove the remaining solvent and the extracts were kept at $-20^{\circ} \mathrm{C}$ until further experiments.

\subsection{Total Phenolic Content}

The total phenolic content of the extract was determined by using Folin-Ciocalteu assay as previously reported [32].

A volume of $10 \mu \mathrm{L}$ of the extract was mixed with $10 \mu \mathrm{L}$ of the Folin-Ciocalteu reagent and $130 \mu \mathrm{L}$ of deionized water and was neutralized with $100 \mu \mathrm{L}$ of $7 \%(w / v)$ sodium carbonate solution. The reaction mixture was incubated in dark at room temperature for $30 \mathrm{~min}$. The absorbance will be determined at the wavelength of $734 \mathrm{~nm}$ by a microplate spectrophotometer (Sunrise, Opfikon, Switzerland). The total phenolic contents are expressed as gallic acid equivalent per gram of extract ( $\mu \mathrm{g}$ GAE/mg dry weight) for the standard curve.

\subsection{Antioxidant Assays}

The antioxidant capacities were measured by 2,2-diphenyl-1-picrylhydrazyl (DPPH), ferric ion reducing antioxidant power (FRAP), 2,2'-azino-bis-(3-ethylbenzothiazoline-6sulfonic acid) (ABTS) and nitric oxide (NO) radical scavenging methods as previously reported [32].

\subsubsection{DPPH Free Radical Scavenging Assay}

A solution of $0.2 \mathrm{mM}$ DPPH $(150 \mu \mathrm{L})$ was incubated with $75 \mu \mathrm{L}$ of the sample dissolved in ethanol for $30 \mathrm{~min}$ in the dark. The absorbance was recorded against a blank at the wavelength of $517 \mathrm{~nm}$. L-Ascorbic acid was used as a positive control. The inhibition percentage was calculated using equation (1) and the capacity to scavenge the DPPH radical by $50 \%\left(\mathrm{IC}_{50}\right)$ was calculated from the dose-effect curves by linear regression.

$$
\% \text { Inhibition }=\left[\left(\mathrm{A}_{\text {control }}-\mathrm{A}_{\text {sample }}\right) / \mathrm{A}_{\text {control }}\right] \times 100
$$

where $A_{\text {sample }}$ is the absorbance of the sample and $A_{\text {control }}$ is the absorbance of reagent solution mixed with ethanol (blank).

\subsubsection{FRAP Radical Scavenging Assay}

Briefly, the solution of $10 \mathrm{mM}$ of 2,4,6-tripyridyl-S-triazine (TPTZ) in $40 \mathrm{mM} \mathrm{HCl}$, $\mathrm{FeCl}_{3} \cdot 6 \mathrm{H}_{2} \mathrm{O}(20 \mathrm{mM})$ and acetate buffer $(\mathrm{pH}$ 3.6) were mixed in the ratio of 1:1:10 to obtain the working FRAP reagent. The reaction mixture was incubated at $37^{\circ} \mathrm{C}$ for $10 \mathrm{~min}$. The test sample $(50 \mu \mathrm{L})$ was mixed with $150 \mu \mathrm{L}$ of working FRAP solution for $10 \mathrm{~min}$ at room temperature. The absorbance of the colored product was measured at the wavelength of $593 \mathrm{~nm}$. L-Ascorbic acid was used as a positive standard. The inhibition percentage was 
calculated using equation (1) and the FRAP activity to scavenge the radical by $50 \%\left(\mathrm{IC}_{50}\right)$ was calculated from the dose-effect curves by linear regression.

\subsubsection{ABTS Radical Scavenging Assay}

The stock solutions which are $7 \mathrm{mM}$ ABTS solution and $2.4 \mathrm{mM}$ potassium persulfate were freshly prepared. These stock solutions were then mixed in equal quantities and allowing them to react for $16-18 \mathrm{~h}$ in the dark. The solution was diluted by mixing $1 \mathrm{~mL}$ $\mathrm{ABTS}^{\bullet+}$ solution with $10 \mathrm{~mL}$ ethanol to obtain an absorbance of less than $0.99 \pm 0.01$ units at $734 \mathrm{~nm}$. The test sample $(15 \mu \mathrm{L})$ was allowed to react with $150 \mu \mathrm{L}$ of the freshly prepared $\mathrm{ABTS}^{\bullet+}$ solution and the absorbance was taken at $734 \mathrm{~nm}$ after $10 \mathrm{~min}$. The ABTS scavenging capacity of the extract will be compared with those of L-ascorbic acid and percentage inhibition calculated using equation (1).

\subsubsection{NO Radical Scavenging Assay}

Briefly, $10 \mathrm{mM}$ sodium nitroprusside (SNP) solution $(60 \mu \mathrm{L})$ was freshly prepared in phosphate buffer saline (pH 7.4) and was mixed with $60 \mu \mathrm{L}$ of the test sample. The mixture was incubated at room temperature for $120 \mathrm{~min}$. Then, $120 \mu \mathrm{L}$ of Griess reagent (a mixture of $1 \%(w / v)$ sulfanilamide in $2.5 \%(v / v) \mathrm{H}_{3} \mathrm{PO}_{4}$ and $0.1 \%(w / v) N-(1$-naphthyl)ethylenediamine dihydrochloride (NED) in $\left.2.5 \%(v / v) \mathrm{H}_{3} \mathrm{PO}_{4}\right)$ was added to the mixed solution, which was incubated at room temperature for $10 \mathrm{~min}$. The incubated solution was measured for absorbance at $550 \mathrm{~nm}$. L-Ascorbic acid was used as a positive control. The percentage of $\mathrm{NO}$ radical scavenging activity in a similar manner of DPPH assay.

\subsection{Isolation of Marker Compounds from Crude Extracts}

The extract of CA was subjected to silica column chromatography, eluting with $n$ hexane, $n$-hexane:EtOAc, and EtOAc by increasing the more polar solvent to give (-)curcumene (1), (-)-xanthorrhizol (2) and germacrone (3) (Figure 1). The spectroscopic $\left({ }^{1} \mathrm{H}\right.$ and ${ }^{13} \mathrm{C}$ NMR, 2D NMR, and mass spectra) data were in agreement with their structures and were consistent with those of the reported values [33-35].<smiles>CC(C)=CCC[C@H](C)c1ccc(C)cc1</smiles>

(1)<smiles>CC(C)=CCC[C@H](C)c1ccc(C)c(O)c1</smiles>

(2)

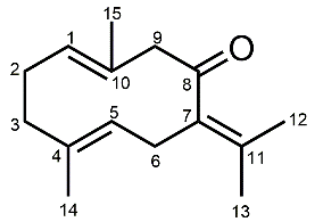

(3)<smiles>Oc1ccc(CC[C@@H](O)CC/C=C/c2ccccc2)cc1O</smiles>

(4)

Figure 1. The structures of marker compounds of C. aromatica (1-3) and C. comosa (4).

(-)-Curcumene (1). Colorless oil; $\alpha_{\mathrm{D}}^{25}-29.1$ ( c 3.81, $\left.\mathrm{CHCl}_{3}\right) ;{ }^{1} \mathrm{H} \mathrm{NMR}\left(400 \mathrm{MHz}, \mathrm{CDCl}_{3}\right)$ $\delta 7.11(2 \mathrm{H}, d, J=8.4 \mathrm{~Hz}, \mathrm{H}-3, \mathrm{H}-5), 7.08(2 \mathrm{H}, d, J=8.4 \mathrm{~Hz}, \mathrm{H}-2, \mathrm{H}-6), 5.11(1 \mathrm{H}$, br t, $7.1 \mathrm{~Hz}$, $\mathrm{H}-10), 2.67$ (1H, m, H-7), 2.33 (3H, s, $\left.\mathrm{CH}_{3}-14\right), 1.88$ (2H, m, H-9), 1.68 (3H, br s, $\left.\mathrm{CH}_{3}-12\right), 1.60$ $(2 \mathrm{H}, m, \mathrm{H}-8), 1.54\left(3 \mathrm{H}\right.$, br s, $\left.\mathrm{CH}_{3}-13\right), 1.23\left(3 \mathrm{H}, d, J=6.9 \mathrm{~Hz}, \mathrm{CH}_{3}-15\right) ;{ }^{13} \mathrm{C} \mathrm{NMR}(100 \mathrm{MHz}$, $\left.\mathrm{CDCl}_{3}\right) \delta 144.6$ (C-1), 135.0 (C-4), 131.2 (C-11), 128.9 (C-3, C-5), 126.8 (C-2, C-6), 124.5 (C-10), 39.0 (C-7), 38.4 (C-8), 26.1 (C-9), $25.6\left(\mathrm{CH}_{3}-12\right), 22.4\left(\mathrm{CH}_{3}-15\right), 20.9\left(\mathrm{CH}_{3}-14\right), 17.6\left(\mathrm{CH}_{3}-13\right)$; HR-TOFMS (ES ${ }^{-}$) $m / z 201.1696$ (calcd for $\mathrm{C}_{15} \mathrm{H}_{21}, 201.1648$ ).

(-)-Xanthorrhizol (2). Pale yellow oil; $\alpha_{\mathrm{D}}^{25}-44.2$ (c 2.82, $\left.\mathrm{CHCl}_{3}\right) ;{ }^{1} \mathrm{H}$ NMR $(400 \mathrm{MHz}$, $\left.\mathrm{CDCl}_{3}\right) \delta 7.01(1 \mathrm{H}, d, J=7.6 \mathrm{~Hz}, \mathrm{H}-6), 6.66(1 \mathrm{H}, d d, J=7.6,1.4 \mathrm{~Hz}, \mathrm{H}-5), 6.59(1 \mathrm{H}, d$, 
$J=1.4 \mathrm{~Hz}, \mathrm{H}-3), 5.07(1 \mathrm{H}, b r t, J=7.1 \mathrm{~Hz}, \mathrm{H}-10), 2.59(1 \mathrm{H}, m, \mathrm{H}-7), 2.20\left(3 \mathrm{H}, s, \mathrm{CH}_{3}-14\right), 1.86$ (2H, m, H-9), $1.66\left(3 \mathrm{H}\right.$, br s, $\left.\mathrm{CH}_{3}-12\right), 1.57(2 \mathrm{H}, m, \mathrm{H}-8), 1.52\left(3 \mathrm{H}\right.$, br s, $\left.\mathrm{CH}_{3}-13\right), 1.18(3 \mathrm{H}$, $\left.d, J=6.9 \mathrm{~Hz}, \mathrm{CH}_{3}-15\right) ;{ }^{13} \mathrm{C} \mathrm{NMR}\left(100 \mathrm{MHz} \mathrm{CDCl}_{3}\right) \delta 153.5$ (C-2), 147.2 (C-4), $131.4(\mathrm{C}-11)$, 130.7 (C-6), 124.4 (C-10), 120.7 (C-1), 119.4 (C-5), 113.5 (C-3), 39.0 (C-7), 38.3 (C-8), 26.1 (C-9), $25.6\left(\mathrm{CH}_{3}-12\right), 22.3\left(\mathrm{CH}_{3}-14\right), 17.6\left(\mathrm{CH}_{3}-13\right), 15.2\left(\mathrm{CH}_{3}-15\right)$; HR-TOFMS (ES $\left.{ }^{-}\right) \mathrm{m} / \mathrm{z} 217.1594$ (calcd for $\mathrm{C}_{15} \mathrm{H}_{21} \mathrm{O}, 217.1597$ ).

Germacrone (3). White amorphous solid; ${ }^{1} \mathrm{H}$ NMR $\left(400 \mathrm{MHz}, \mathrm{CDCl}_{3}\right) \delta 4.95(1 \mathrm{H}, b r$ $d, J=11.0 \mathrm{~Hz}, \mathrm{H}-1), 4.68(1 \mathrm{H}, b r d d, J=11.3,2.7 \mathrm{~Hz}, \mathrm{H}-5), 3.38(1 \mathrm{H}, d, J=10.5 \mathrm{~Hz}, \mathrm{H}-9 \mathrm{~b})$, $2.92(1 \mathrm{H}, d, J=10.5 \mathrm{~Hz}, \mathrm{H}-9 \mathrm{a}), 2.91$ (1H, br d, $J=12.5 \mathrm{~Hz}, \mathrm{H}-6 \mathrm{~b}), 2.82(1 \mathrm{H}$, br dd, J = 12.5, $2.8 \mathrm{~Hz}, \mathrm{H}-6 \mathrm{a}), 2.32$ (1H, partially overlapping signal, $\mathrm{H}-2 \mathrm{~b}), 2.13(1 \mathrm{H}$, partially overlapping signal, H-3b), $2.08(1 \mathrm{H}$, partially overlapping signal, $\mathrm{H}-3 \mathrm{a}), 2.05(1 \mathrm{H}$, partially overlapping signal, $\mathrm{H}-2 \mathrm{a}), 1.74\left(3 \mathrm{H}, \mathrm{s}, \mathrm{CH}_{3}-12\right), 1.69\left(3 \mathrm{H}, s, \mathrm{CH}_{3}-13\right), 1.59\left(3 \mathrm{H}, d, J=2.7 \mathrm{MHz}, \mathrm{CH}_{3}-14\right)$, $1.41\left(3 \mathrm{H}\right.$, br s, $\left.\mathrm{CH}_{3}-15\right) ;{ }^{13} \mathrm{C}$ NMR $\left(100 \mathrm{MHz}, \mathrm{CDCl}_{3}\right) \delta 207.8$ (C-8), 137.2 (C-11), 134.9 (C-4), 132.6 (C-1), 129.4 (C-10), 126.6 (C-7), 125.3 (C-5), 55.8 (C-9), 38.0 (C-3), 29.2 (C-6), 24.0 (C-2), $22.3\left(\mathrm{CH}_{3}-13\right), 19.8\left(\mathrm{CH}_{3}-12\right), 16.7\left(\mathrm{CH}_{3}-14\right), 15.5\left(\mathrm{CH}_{3}-15\right) ;$ HR-TOFMS $\left(\mathrm{ES}^{+}\right) \mathrm{m} / z 241.1530$ (calcd for $\mathrm{C}_{15} \mathrm{H}_{22} \mathrm{ONa}$, 241.1562).

Column chromatography of the CC extract eluting with the isocratic solvent system of n-hexane:EtOAc (3:2) gave (3S)-1-(3,4-dihydroxyphenyl)-7-phenyl-(6E)-6-hepten-3-ol (4). The spectroscopic $\left({ }^{1} \mathrm{H}\right.$ and ${ }^{13} \mathrm{C}$ NMR, 2D NMR, and mass spectra) data were in agreement with the structure and were consistent with those of the reported values [24].

(3S)-1-(3,4-Dihydroxyphenyl)-7-phenyl-(6E)-6-hepten-3-ol (4). White amorphous solid; $\left.\alpha_{\mathrm{D}}^{24}-19.9\left(c \mathrm{c} 0.77, \mathrm{CHCl}_{3}\right) ;{ }^{1} \mathrm{H} \mathrm{NMR}\left(400 \mathrm{MHz}^{\mathrm{CDCl}}\right)_{3}\right) \delta .30(2 \mathrm{H}, t d, J=8.5,1.8 \mathrm{~Hz}, \mathrm{H}-3$ ", H-5"), $7.26\left(2 \mathrm{H}, d d, J=8.5,1.6 \mathrm{~Hz}, \mathrm{H}-2^{\prime \prime}, \mathrm{H}-6^{\prime \prime}\right), 7.18\left(1 \mathrm{H}, t d d, J=8.5,1.8,1.6 \mathrm{~Hz}, \mathrm{H}-4^{\prime \prime}\right), 6.74$ $\left(1 \mathrm{H}, d, J=8.1 \mathrm{~Hz}, \mathrm{H}-5^{\prime}\right), 6.68\left(1 \mathrm{H}, d, J=1.9 \mathrm{~Hz}, \mathrm{H}-2^{\prime}\right), 6.59\left(1 \mathrm{H}, d d, J=8.1,1.9 \mathrm{~Hz}, \mathrm{H}-6^{\prime}\right)$, $6.38(1 \mathrm{H}$, br d, $J=15.8 \mathrm{~Hz}, \mathrm{H}-7), 6.19(1 \mathrm{H}, d t, J=15.8,6.9 \mathrm{~Hz}, \mathrm{H}-6), 5.52(1 \mathrm{H}$, br s, 3'-OH), $5.31(1 \mathrm{H}$, br s, 4'-OH), $3.68(1 \mathrm{H}, m, \mathrm{H}-3), 2.65(1 \mathrm{H}, m, \mathrm{H}-1 \mathrm{~b}), 2.55(1 \mathrm{H}, m, \mathrm{H}-1 \mathrm{a}), 2.30(1 \mathrm{H}, m$, $\mathrm{H}-5), 1.73$ (1H, m, H-2), 1.63 (1H, m, H-4); ${ }^{13} \mathrm{C}$ NMR (100 MHz, CDCl 3 ) $\delta 143.5\left(\mathrm{C}-4^{\prime}\right), 141$. 7 (C-3'), 137.5 (C-1'), 134.9 (C-1"), 130.3 (C-7), 130.2 (C-6), 128.5 (C-2", C-6"), 126.9 (C-4"), 125.9 (C-3", C-5"), 120.6 (C-6), 115.4 (C-2'), 115.3 (C-5'), 71.0 (C-3), 39.0 (C-2), 36.9 (C-4), 31.3 (C-1), 29.2 (C-5); HR-TOFMS (ES ${ }^{+}$) m/z 321.1469 (calcd for $\mathrm{C}_{19} \mathrm{H}_{22} \mathrm{O}_{3} \mathrm{Na}, 321.1461$ ).

\subsection{Quantification of Marker Compounds in Crude Extracts using High-Performance Liquid Chromatography-Diode Array (HPLC-DAD)}

The purity of isolated marker compounds 1-4 was determined by ${ }^{1} \mathrm{H}$ NMR and HPLC techniques. The quantity of marker compounds in the extract was determined using Agilent 1200 series HPLC system equipped with a G1311A pump and a G1315B DAD detector (Agilent Technologies, CA, USA).

For CA, the extract and each of the marker compounds 1-3 were accurately weighed and separately dissolved in isopropanol, filtered through a $0.22 \mu \mathrm{m}$ nylon filter and the solution of each sample was injected into Phenomenex Luna Silica (2) $(250 \times 4.60 \mathrm{~mm} \times 5 \mu \mathrm{m})$ column (Phenomenex, CA, USA) at a column temperature of $25^{\circ} \mathrm{C}$. The mobile phase consisted of $n$-hexane (solvent A) and isopropanol (solvent $\mathrm{B}$ ). The elution program was optimized as follows: $0.0-6.0 \mathrm{~min}, 0.5 \% \mathrm{~B}$, flow rate $1.0 \mathrm{~mL} / \mathrm{min} ; 6.0-6.3 \mathrm{~min}, 0.5 \% \mathrm{~B}$, flow rate $1.8 \mathrm{~mL} / \mathrm{min}$; $6.3-19.0 \mathrm{~min}, 1 \% \mathrm{~B}$, flow rate $1.8 \mathrm{~mL} / \mathrm{min}$; $19.0-30.0 \mathrm{~min}, 0.5 \% \mathrm{~B}$, flow rate $1.0 \mathrm{~mL} / \mathrm{min}$. The injected volume was $50 \mu \mathrm{L}$ and monitored at $214 \mathrm{~nm}$.

For CC, the extract and marker compound 4 were prepared in a similar manner to those of the CA extract analysis, except that acetonitrile has been used in place of isopropanol. The analytical column was a $250 \times 4.60 \mathrm{~mm} \times 5 \mu \mathrm{m}$ Phenomenex Luna reverse phase $\mathrm{C}_{18}$ column (Phenomenex, CA, USA) at a column temperature of $25{ }^{\circ} \mathrm{C}$. Mobile phase A was $0.5 \%(v / v)$ acetic acid in water and mobile phase B was acetonitrile. The gradient elution program was optimized as follows: 0.0-5.0 $\mathrm{min}, 70 \% \mathrm{~B} ; 5.0-10.0 \mathrm{~min}$, $75 \% \mathrm{~B} ; 10-15.0 \mathrm{~min}, 80 \% \mathrm{~B} ; 15.0-25.0 \mathrm{~min}, 90 \% \mathrm{~B}$. The analysis was carried out at a constant flow rate of $1.0 \mathrm{~mL} \mathrm{~min}^{-1}$. The injected volume was $50 \mu \mathrm{L}$ and was monitored at $254 \mathrm{~nm}$. The amount of marker compounds was calculated by using the peak integration of each 
compound using a calibration curve generated from isolated pure marker compounds. All experiments were performed in triplicate.

\subsection{Validation of HPLC Analysis}

Validation of HPLC analysis was performed using the purified marker compounds. Calibration curves were conducted from the peak areas of the standards 1-4 versus their seven different concentrations in the range of $3.91-250.00 \mu \mathrm{g} / \mathrm{mL}(\mathbf{1}-\mathbf{3})$ and $1.95-125.00 \mu \mathrm{g} / \mathrm{mL}$ (4). The linearity of the calibration curves was evaluated using correlation coefficients $\left(R^{2}\right)$. The limit of detection (LOD) and the limit of quantification (LOQ) were determined as signal-tonoise $(\mathrm{S} / \mathrm{N})$ ratios of 3 and 10 , respectively. The precision of the method was determined via a repeatability test within one day (intra-day) and an intermediate precision over three days (inter-day). Intra-day analysis was performed by analyzing the same standard solutions at three different concentrations $(7.81,31.25$ and $125.00 \mu \mathrm{g} / \mathrm{mL}$ for compounds $\mathbf{1}-\mathbf{3}$ and 3.91, 15.63 and $62.50 \mu \mathrm{g} / \mathrm{mL}$ for compound 4 ) in a single day and inter-day analysis was achieved by analyzing standard solutions at three different concentrations on three consecutive days, respectively. Precisions are given as relative standard deviations (RSDs) (where \% RSD = (standard deviation $/$ mean) $\times 100$ ). The accuracy of the method was determined by the recovery test. Recovery was calculated as follows: \% recovery $=(($ detected concentration initial concentration)/spiked concentration) $\times 100$.

\subsection{Cell Line and Culture Conditions}

The HaCaT cells were purchased from CLS Cell Lines Service GmbH (Eppelheim, Germany). They were maintained in Dulbecco's modified Eagle's medium (DMEM) (GIBCO, Paisley, UK) supplemented with 10\% $(v / v)$ fetal bovine serum (GIBCO, Paisley, UK) and $1 \%(v / v)$ penicillin/streptomycin (GIBCO, Paisley, UK). Cells were grown at $37^{\circ} \mathrm{C}$ in a humidified $5 \% \mathrm{CO}_{2}$ atmosphere. When cells (from passages 16 to 25 ) reached $70-80 \%$ confluence, they were trypsinized, planted at different densities according to the parameters studied, and incubated for $24 \mathrm{~h}$.

\subsection{UV Irradiation}

The HaCaT cells $\left(5 \times 10^{5}\right.$ cell dish $\left.^{-1}\right)$ were seeded into a $60 \mathrm{~mm}$ Petri dish and were incubated in cultured media for $24 \mathrm{~h}$. Prior to UVB exposure, cells were washed with PBS. Cells were exposed to various intensities of UVB $\left(50,100,200\right.$, and $400 \mathrm{~mJ} \mathrm{~cm}^{-2}$ ) under a thin layer of PBS. Philips TL 20W/01 UVB Narrowband TL lamps with an emission spectrum between 290 and $315 \mathrm{~nm}$ (peak, 310-315 nm) were used as the UVB source. The UVB source was positioned at $30 \mathrm{~cm}$ above the cell culture dishes. Sentry UV meter (model ST513, New Taipei City, Taiwan) was used to measure UV irradiance. Immediately after UVB irradiation, PBS was replaced with serum-free media for $24 \mathrm{~h}$. Cell dishes were then repeatedly UVB-irradiated 10 times. The protocol for UVB irradiation is illustrated in Figure 2. After $24 \mathrm{~h}$ of the last irradiation, the culture media was removed and MTS solution was added into the culture dishes and further incubated for $4 \mathrm{~h}$. The cell viabilities were quantified by the absorbance at $493 \mathrm{~nm}$ using a microplate spectrophotometer. The absorbance of the non-UVB-exposed cells was adjusted to $100 \%$ viability. Cell morphology was observed using an inverted microscope. 


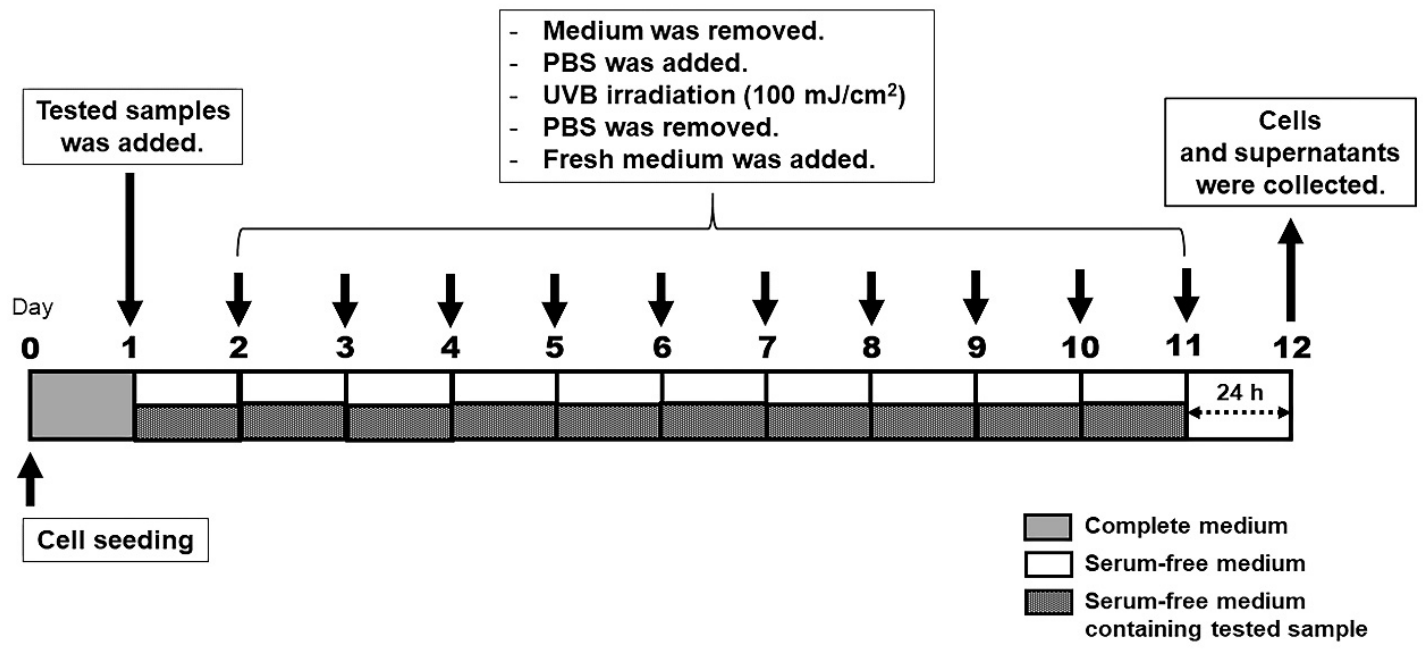

Figure 2. Schematic illustration of the protocol of repeated UVB irradiation.

\subsection{Cell Viability}

To determine the effect of non-toxic concentrations of CA and CC extracts, cell viability was evaluated by MTS assay. The HaCaT cells $\left(2 \times 10^{4}\right.$ cells/well) were seeded into 96-well plates and were maintained until $80 \%$ confluency, and the cells were pre-treated with serumfree medium or serum-free medium containing the extracts for $24 \mathrm{~h}$. The cells were washed with PBS and irradiated (or non-irradiated for the control group) with UVB under a thin layer of PBS. After irradiation, the cells were then placed in a fresh serum-free medium and continuedly incubated for $24 \mathrm{~h}$. After incubation, the culture media was removed and MTS solution was added into culture plates and further incubated for $4 \mathrm{~h}$. The cell viabilities were quantified by the absorbance at $493 \mathrm{~nm}$ using a microplate spectrophotometer. The absorbance of the non-UVB-exposed cells was adjusted to $100 \%$ viability. Cell morphology was observed using an inverted microscope.

\subsection{Cell Proliferation}

To determine the effect of CA and CC extracts and their isolated constituents on cell proliferation, the HaCaTs were evaluated by trypan blue exclusion assays. Briefly, the cells were seeded into a $60 \mathrm{~mm}$ Petri dish at $5 \times 10^{5}$ cells/dish and then incubated in a humidified atmosphere $\left(37^{\circ} \mathrm{C}, 5 \% \mathrm{CO}_{2}\right)$ for $24 \mathrm{~h}$. Cells were then repeatedly UVBirradiated 10 times as described in Figure 2. After $24 \mathrm{~h}$ of the last UVB exposure, cells were trypsinized and stained with $0.4 \%$ trypan blue solution (GIBCO, Paisley, UK). Enumeration of viable cells was carried out under a phase-contrast microscope with a hemocytometer.

\subsection{Enzyme-Linked Immunosorbent Assay (ELISA)}

The release of MMP-1 in UVB-irradiated HaCaT cells was analyzed by the ELISA technique. The HaCaT cells $\left(5 \times 10^{5}\right.$ cells/dish) were pre-incubated in a $60 \mathrm{~mm}$ Petri dish for $24 \mathrm{~h}$, and the cells were pre-treated with serum-free medium or serum-free medium containing the extracts or the isolated compounds for $24 \mathrm{~h}$. Cell dishes were washed with PBS before UVB exposure $\left(100 \mathrm{~mJ} / \mathrm{cm}^{2}\right)$ under a thin layer of PBS. Immediately after UVB irradiation, the cells were treated with a serum-free medium and further incubated for another $24 \mathrm{~h}$. Cell dishes were then repeatedly UVB-irradiated 10 times. The protocol for cell treatment and irradiation is shown in Figure 2. Supernatant from each well was collected after $24 \mathrm{~h}$ of the last irradiation and analyzed for its MMP-1 contents by the manufacturer's instructions of the ELISA kit.

\subsection{Cell-cycle by Flow Cytometry}

The $\mathrm{HaCaT}$ cells were maintained and repeatedly UVB-irradiated 10 times as described in Figure 2. After $24 \mathrm{~h}$ of the last UVB-irradiation and the removal of supernatants, the cells 
were washed twice with PBS, fixed and permeabilized with ice-cold 70\% $(v / v)$ ethanol, and washed with PBS. The cultures were then resuspended in Guava cell-cycle reagent. The cell-cycle analyses were performed using a Guava easyCyte 8HT flow cytometer (Merck Millipore, Darmstadt, Germany). The percentage of cells in the different stages of the cell cycle was assessed by a flow cytometer and analyzed with Guava Cell-Cycle software. The obtained results were expressed as the percentage of cells in the different stages of the cell cycle in treated cultures compared to that present in the control cultures.

\subsection{Statistical Analysis}

The results are presented as means \pm SD, and statistical analyses were performed using a Student's $t$-test by using GraphPad Prism version 7.00 for Windows software (La Jolla, CA, USA). $p$-Values $<0.05$ were considered to indicate a statistically significant.

\section{Results and Discussion}

\subsection{Extraction and Isolation}

In preliminary screening for anti-photoaging agents, it was found that the ethanolic extracts of CA and CC exerted cytoprotective activity against UVB irradiation in human $\mathrm{HaCaT}$ keratinocytes by inducing the expression of MMP-1. This result prompts us to investigate phytochemical constituents from both CA and CC extracts, in order to clarify their anti-MMP-1 expression.

Briefly, the air-dried powder of the CA and CC rhizomes was extracted by the alcoholic maceration method. The yield of the ethanolic extract of CA was $10.8 \%$ and that of the CC extract was 9.6\%. The chromatographic investigation of the ethanol extract of the rhizomes of CA led to the isolation of three major compounds, (-)-curcumene (1), (-)xanthorrhizol (2) and germacrone (3). Additionally, the investigation of the ethanolic extract of the CC rhizomes resulted in the isolation of the major diarylheptanoid 4 [24] as the active constituent. Their structures were identified based on spectroscopic data and by comparisons with those of the reported values. The purity of isolated compounds 1-4 was more than $95 \%$, determined by ${ }^{1} \mathrm{H}$ NMR and HPLC techniques. The extracts and these compounds were then used for further experiments.

\subsection{Antioxidant Activities of CA and CC Extracts}

Oxidative stress is a pathological state, in which the reactive oxygen species (ROS) lead to oxidative modification of biomacromolecules, tissue injury, and accelerated cellular aging and death [36]. Excessive UVB exposure is a primary environmental condition that contributes to the development of skin disorders. Particularly, UVB exposure produces ROS, which damages DNA. This damage eventually leads to skin inflammation, photoaging, and photocarcinogenesis. The incident can be prevented by applying anti-oxidative agents that reduce the damage [37].

The total phenolic contents and $\mathrm{IC}_{50}$ of the antioxidant activities of the ethanol extracts of CA and CC are shown in Table 1. Total phenolic contents of CA and CC extracts were determined by using Folin-Ciocalteu method, which was 90.89 and $186.99 \mu \mathrm{g} \mathrm{GAE} / \mathrm{mg}$, respectively. The antioxidant potency of CC extract obtained by $\mathrm{NO}$ assay $\left(\mathrm{IC}_{50} 0.26 \mu \mathrm{g} / \mathrm{mL}\right)$ showed higher potency than those obtained by ABTS $\left(\mathrm{IC}_{50} 2.67 \mu \mathrm{g} / \mathrm{mL}\right), \mathrm{DPPH}\left(\mathrm{IC}_{50}\right.$ $21.22 \mu \mathrm{g} / \mathrm{mL}$ ) and FRAP ( $\mathrm{IC}_{50} 32.47 \mu \mathrm{g} / \mathrm{mL}$ ) assays, respectively, whereas CA extracts indicated antioxidant property against ABTS (IC $5019.17 \mu \mathrm{g} / \mathrm{mL}), \mathrm{DPPH}\left(\mathrm{IC}_{50} 78.77 \mu \mathrm{g} / \mathrm{mL}\right)$, FRAP ( $\left.\mathrm{IC}_{50} 86.85 \mu \mathrm{g} / \mathrm{mL}\right)$ and $\mathrm{NO}\left(\mathrm{IC}_{50} 159.90 \mu \mathrm{g} / \mathrm{mL}\right)$ assays. In cellular metabolism of the living body, free radical ROS and reactive nitrogen species (RNS) including hydroxyl, superoxide and nitric oxide radicals and non-free radical species including hydrogen peroxide, singlet oxygen and peroxynitrite are present. Various assays are used to investigate the antioxidant capacity of the tested samples. In general, DPPH and ABTS methods use a single-electron transfer mechanism to determine the antioxidant capacity of the tested compounds because they are simple and widely used approaches for determining antioxidant activity. FRAP assay evaluates via the reduction of ferric iron $\left(\mathrm{Fe}^{3+}\right)$ to ferrous iron $\left(\mathrm{Fe}^{2+}\right)$ 
mechanism, while NO is another free radical that reacts with superoxide anion radical to form peroxynitrite, which can effectively detect by using Griess's reagent [38]. The differences in the antioxidant properties of both crude extracts were related to their chemical constituents and phenol concentration that are responsible for the antioxidant potential [39]. The CC extract mainly contains phenolic components, such as diarylheptanoids, which can play an important role in neutralizing free radical species. This causes the CC extract to show higher activity than the CA extract that contains a rich source of terpenoids, which are non-phenolic compounds. However, both CA and CC extracts exhibited less activity than the reference compound, L-ascorbic acid, which is known to be an outstanding antioxidant.

Table 1. Total phenolic contents and antioxidant activities of CA and CC extracts.

\begin{tabular}{|c|c|c|c|c|c|}
\hline \multirow{2}{*}{ Sample } & \multirow{2}{*}{$\begin{array}{l}\text { Total Phenolic Contents } \\
\text { ( } \mu \mathrm{g} \text { GAE/mg) }\end{array}$} & \multicolumn{4}{|c|}{ Antioxidant Activities $\left(\mathrm{IC}_{50}, \mu \mathrm{g} / \mathrm{mL}\right)$} \\
\hline & & DPPH & ABTS & FRAP & NO \\
\hline CA extract & $90.89 \pm 0.14$ & $78.77 \pm 1.02$ & $19.17 \pm 0.07$ & $86.85 \pm 1.11$ & $159.90 \pm 1.04$ \\
\hline CC extract & $186.99 \pm 0.01$ & $21.22 \pm 1.01$ & $2.67 \pm 1.02$ & $32.47 \pm 1.04$ & $0.26 \pm 1.04$ \\
\hline L-Ascorbic acid ${ }^{1}$ & - & $5.15 \pm 1.04$ & $0.86 \pm 1.03$ & $2.06 \pm 1.56$ & $0.04 \pm 1.04$ \\
\hline
\end{tabular}

The results were expressed as mean \pm standard deviation (SD) of triplicate experiments. $(n=3){ }^{1}$ L-Ascorbic acid was used as the positive control.

\subsection{Validation and Quantitative Analysis of Marker Compounds by using HPLC}

The linearity for compounds (1-4) was established by plotting the peak area (y) versus the concentration $(\mathrm{x})$ of each analytical marker, as demonstrated by the equations shown in Table 2. All the standard curves showed good linearity $\left(\mathrm{R}^{2}>0.999\right)$ within the tested ranges [40]. The LOD and LOQ for all the analytes are summarized in Table 2. To assess repeatability, the solutions of the same sample were analyzed. The precision was evaluated on inter-day and intra-day variations by performing three different concentrations with each triplicated experiment of the standard marker. The RSDs were all less than 2\%, which indicates that the method has good repeatability [41]. The accuracy was studied by spiking markers in the analytical sample. The percent recovery was found to be in the range of $95-105 \%$, which remarks that the accuracy of method analysis is acceptable [41]. The established method was identified as a suitable method for quantitative analysis of these samples.

Table 2. Validation of HPLC analysis of marker compounds of CA (1-3) and CC (4).

\begin{tabular}{cccccccc}
\hline \multirow{2}{*}{ Compounds } & Linearity & $\begin{array}{c}\text { Correlation } \\
\text { Coefficient }\end{array}$ & $\begin{array}{c}\text { LOD } \\
(\boldsymbol{\mu} / \mathbf{m L})\end{array}$ & $\begin{array}{c}\text { LOQ } \\
(\boldsymbol{\mu} \mathbf{g} / \mathbf{m L})\end{array}$ & $\begin{array}{c}\text { Inter-Day } \\
(\boldsymbol{n}=\mathbf{9})\end{array}$ & $\begin{array}{c}\text { Intra-Day } \\
(\boldsymbol{n}=\mathbf{9})\end{array}$ & \% Recovery \\
\hline 1 & $\mathrm{y}=91.53 \mathrm{x}+427.86$ & 0.9990 & 1.48 & 4.72 & $0.45 \pm 0.09$ & $0.63 \pm 0.30$ & $98.93 \pm 1.06$ \\
2 & $\mathrm{y}=89.04 \mathrm{x}+272.38$ & 0.9992 & 0.89 & 2.85 & $1.17 \pm 0.16$ & $0.58 \pm 0.39$ & $101.79 \pm 1.48$ \\
3 & $\mathrm{y}=98.72 \mathrm{x}+560.04$ & 0.9992 & 0.42 & 1.34 & $1.30 \pm 0.35$ & $0.65 \pm 0.10$ & $100.43 \pm 0.35$ \\
4 & $\mathrm{y}=174.91 \mathrm{x}+165.03$ & 0.9997 & 0.05 & 0.15 & $0.98 \pm 0.18$ & $1.53 \pm 0.59$ & $99.13 \pm 0.60$ \\
\hline
\end{tabular}

The letters $\mathrm{y}$ and $\mathrm{x}$ are peak area and concentration, respectively.

To explicate the quantity of chemical constituents responsible for the anti-MMP-1 activity in the extracts, the sesquiterpenoids 1-3 in the CA extract and the diarylheptanoid 4 in the CC extract were quantified by using HPLC/DAD. The ethanol extract of CA contained compound $1(192.76 \pm 10.59 \mu \mathrm{g} / \mathrm{mg})$, compound $2(168.04 \pm 15.55 \mu \mathrm{g} / \mathrm{mg})$ and compound $3(40.91 \pm 0.85 \mu \mathrm{g} / \mathrm{mg})$. These sesquiterpenoids are mainly phytochemical constituents in CA extract by our preliminary investigation. In addition, the diarylheptanoid $4\left(128.07 \pm 16.38 \mu \mathrm{g} \mathrm{mg}^{-1}\right)$ was also quantified as the active compound of CC ethanolic extract. The HPLC chromatograms of compounds 1-4 are shown in Figures 3 and 4. 


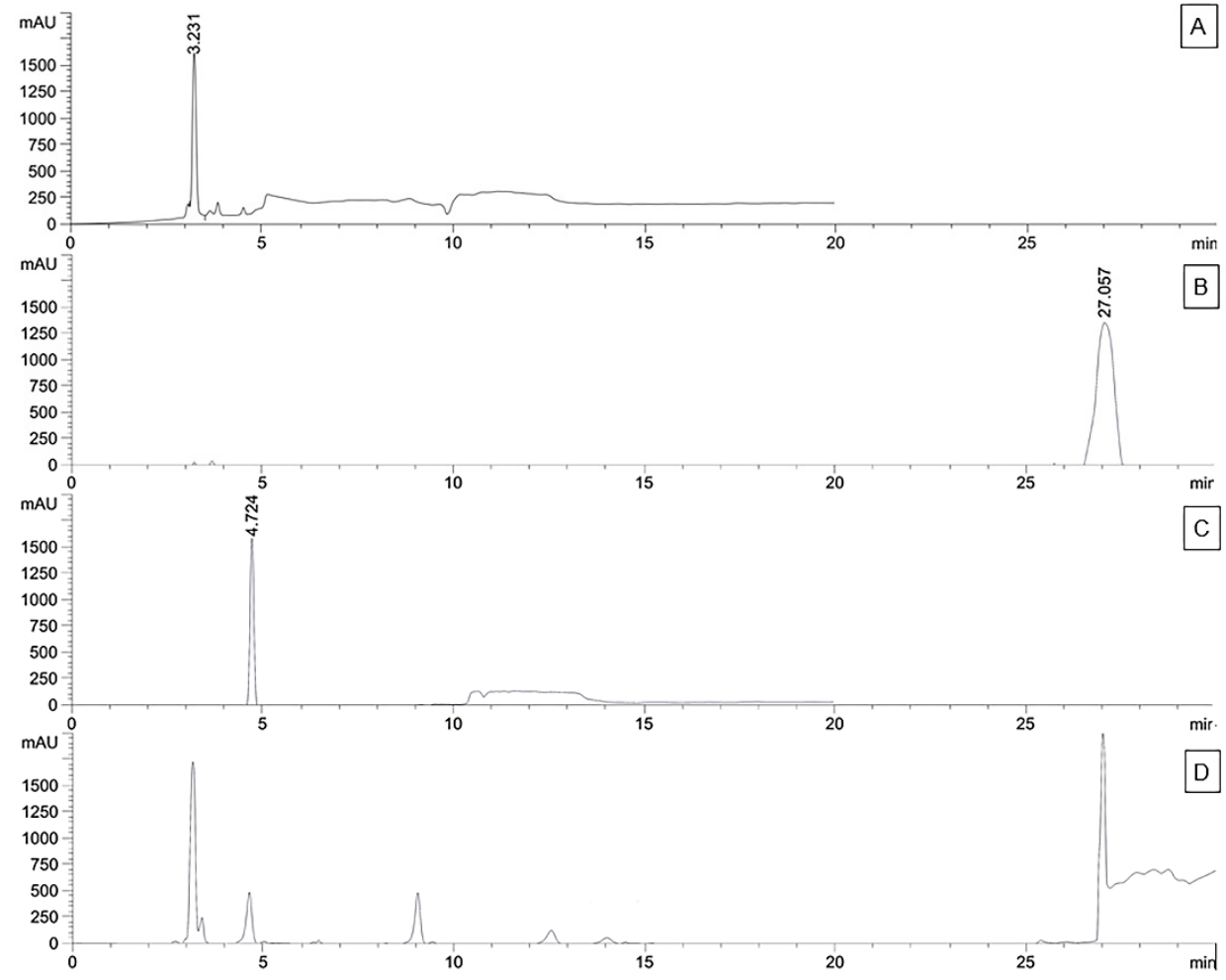

Figure 3. HPLC chromatograms of (A) compound 1, (B) compound 2, (C) compound 3 and (D) crude extract of CA.

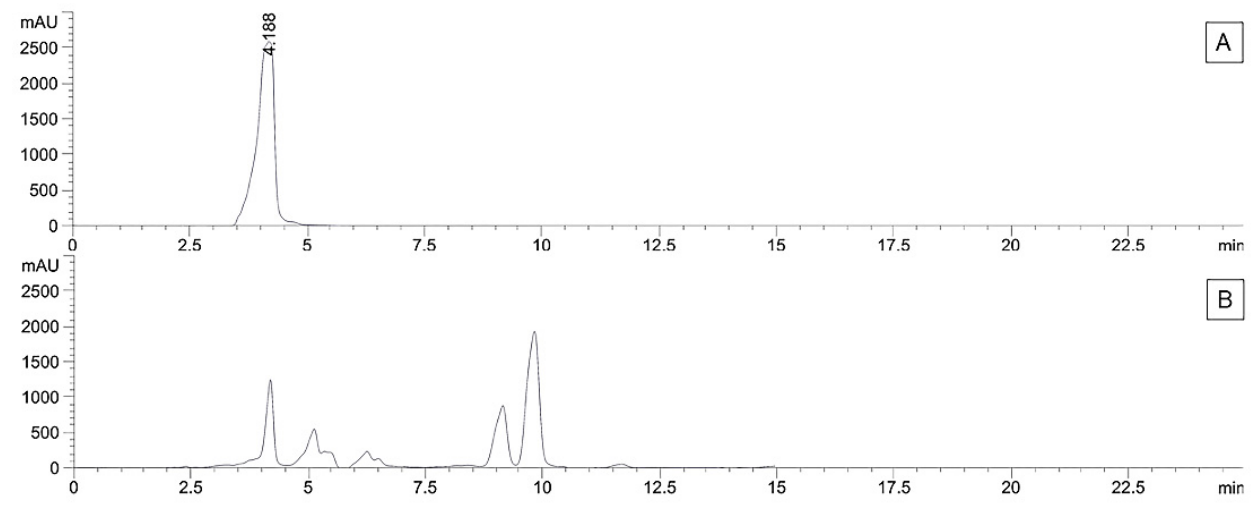

Figure 4. HPLC chromatograms of (A) compound 4 and (B) crude extract of CC.

\subsection{Selection of Optimal UVB Dose}

To investigate the optimal UVB dose, the HaCaT cells were irradiated with dosedependent of UVB at 50,100,200, and $400 \mathrm{~mJ} / \mathrm{cm}^{2}$. The results showed that most of the tested UVB doses (50, 100, and $200 \mathrm{~mJ} / \mathrm{cm}^{2}$ ) did not affect HaCaT viability (Figure 5A). However, the typical morphology of the non-UVB-irradiated group (Figure 5B) partially changed at the UVB irradiation dose of $200 \mathrm{~mJ} / \mathrm{cm}^{2}$ (Figure $5 \mathrm{E}$ ), whereas a dose of $100 \mathrm{~mJ} / \mathrm{cm}^{2}$ or less did not change the morphology of cells (Figure 5C,D). In addition, the latter maximum dose of $400 \mathrm{~mJ} / \mathrm{cm}^{2}$ did injure cells, leading to cell death (Figure 5F). Therefore, a UVB dose of $100 \mathrm{~mJ} / \mathrm{cm}^{2}$ was selected for further experiments. 


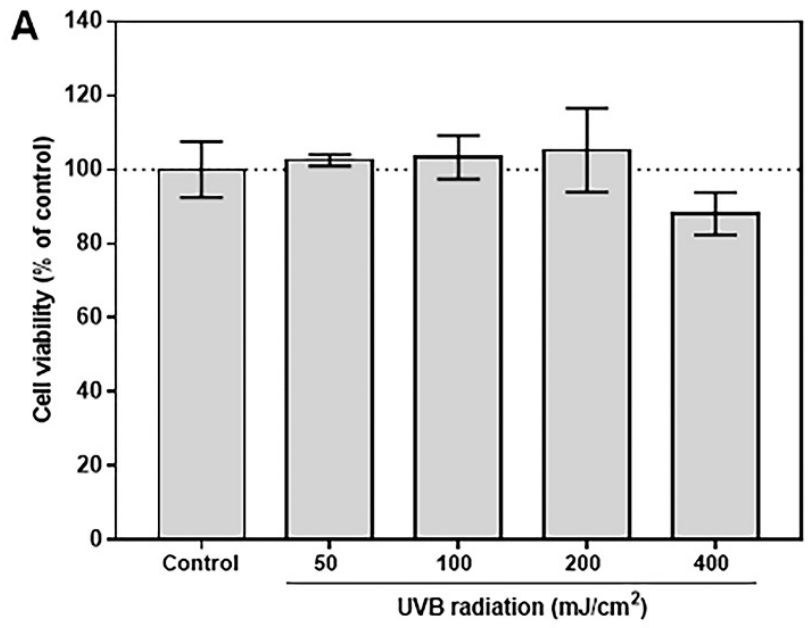

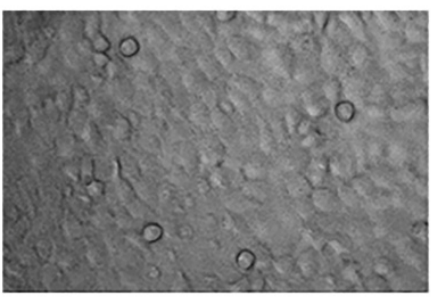

(B)

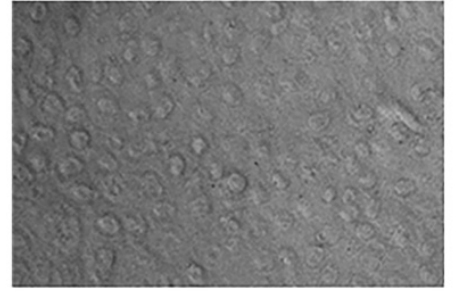

(E)

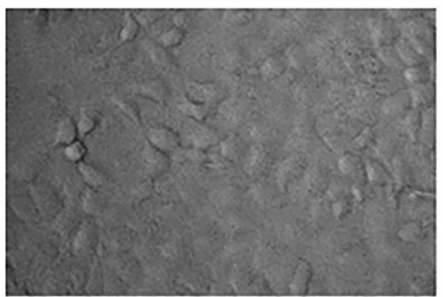

(C)

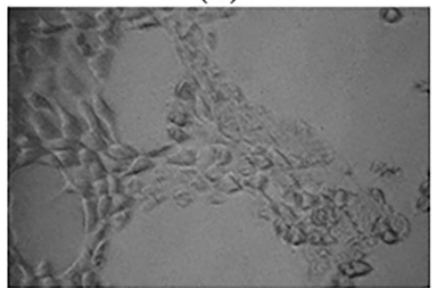

(F)

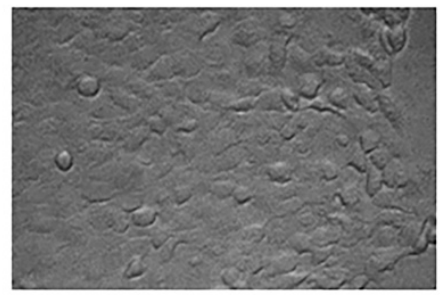

(D)

Figure 5. Effect of UVB irradiation on HaCaT viability. Cells were irradiated with various UVB intensities. They were then incubated in a culture medium for $24 \mathrm{~h}$. (A) Cytotoxicity was conducted by MTS assay of non-UVB-irradiated and UVB-irradiated cells (100\% of control). Data are presented as means \pm S.D. Morphologies of (B) non-UVB-irradiated cells or cells irradiated with UVB at a dose of (C) $50 \mathrm{~mJ} / \mathrm{cm}^{2}$, (D) $100 \mathrm{~mJ} / \mathrm{cm}^{2}$, (E) $200 \mathrm{~mJ} / \mathrm{cm}^{2}$, and (F) $400 \mathrm{~mJ} / \mathrm{cm}^{2}$.

\subsection{Cytotoxicity of the Extracts to Human HaCat Keratinocytes}

To assess the effects of CA and CC extracts on cell viability, the MTS assay, according to the previous study [42] with some modifications was used in this investigation. The MTS tetrazolium compound is reduced by viable cells to produce a colored formazan dye that is soluble in cell culture medium in this colorimetric assay. In metabolically active cells, NAD(P)H-dependent dehydrogenase enzymes are responsible for this conversion. A change in the amount of formazan generated in response to an increase or reduction of viable cells indicates the degree of cytotoxicity. Compared with cells treated with $0.1 \%$ $(v / v)$ DMSO, both extracts did not significantly affect the viability of HaCaT keratinocyte cells (>80\% viability) at the examined concentrations of $0.05-0.50 \mu \mathrm{g} \mathrm{mL}{ }^{-1}$ for CA and $0.05-1.00 \mu \mathrm{g} / \mathrm{mL}$ for CC after incubation for $24 \mathrm{~h}$. However, the higher concentration of both extracts showed cytotoxicity against $\mathrm{HaCaT}$ cells (Figure 6). Thus, the concentrations of $0.50 \mu \mathrm{g} / \mathrm{mL}$ for $\mathrm{CA}$ and $1.00 \mu \mathrm{g} / \mathrm{mL}$ for $\mathrm{CC}$ were chosen for further experiments. 


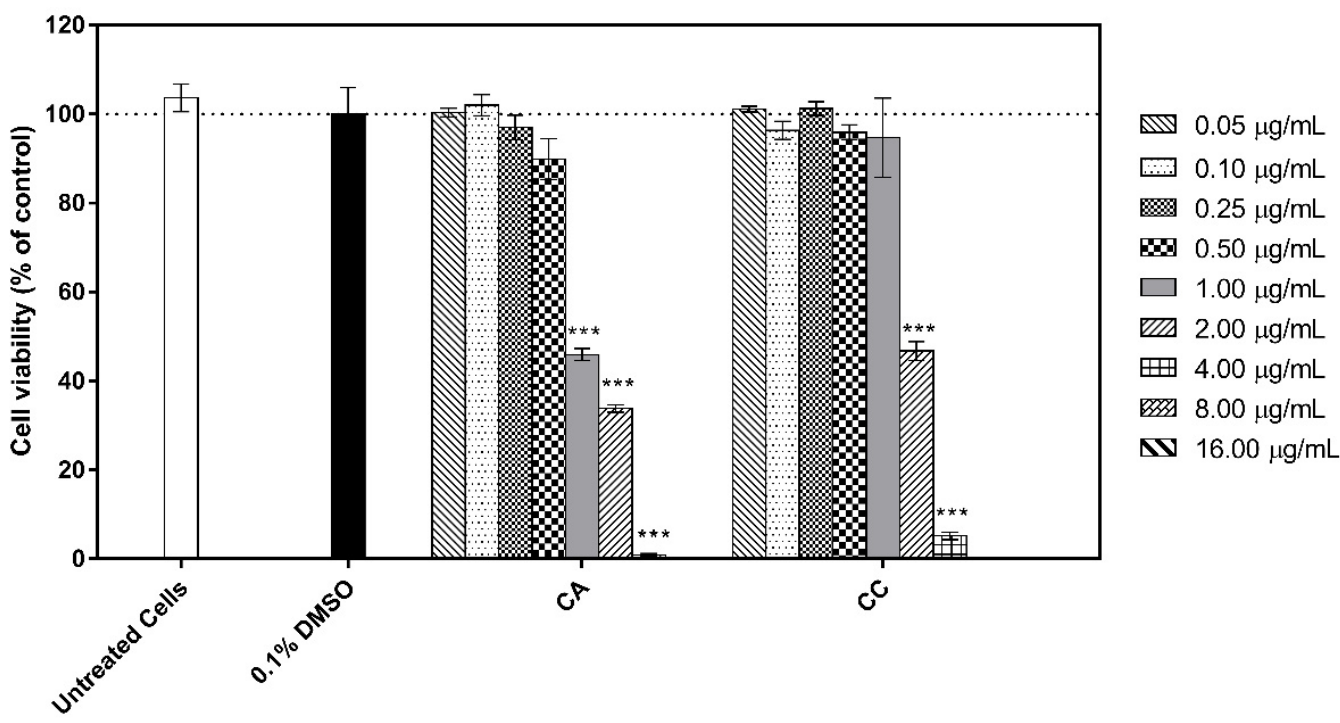

Figure 6. Cytotoxicity of CA and CC extracts against human HaCaT keratinocytes. Data are presented as the means $\pm \mathrm{SD}$. ${ }^{* * *} p<0.05$ compared to the control $(0.1 \% \mathrm{DMSO})$.

3.6. Evaluation of the Extracts and Isolated Constituents on Cell Proliferation and MMP-1 after UVB Irradiation in Human HaCaT Keratinocyte Cells

To test the effects of the CA and CC extracts together with their isolated compounds on cell proliferation, $\mathrm{HaCaT}$ cells were pre-treated with the serum-free medium containing the tested sample and were then repeatedly UVB-irradiated $\left(100 \mathrm{~mJ} / \mathrm{cm}^{2} \times 10\right.$ times). The cell treatment and irradiation protocol are demonstrated in Figure 2. A concentration of CA and CC extracts was used based on cytotoxic results ( 0.50 and $1.00 \mu \mathrm{g} / \mathrm{mL}$, respectively); whereas a dose of isolated compounds 1-4 was treated with an equivalent amount in crude extracts, which was then quantified by the HPLC technique. After $24 \mathrm{~h}$ of the tenth UVBirradiation, the total number of viable cells was then counted using trypan blue staining and a hemocytometer. In the UVB-treated control group, cell numbers significantly decreased compared with the untreated group (Figure 7). Pre-treatment with the CA and CC extracts and their isolated compounds $\mathbf{1} \mathbf{- 4}$ before repeated UVB irradiation markedly enhanced the cell proliferation compared with the UVB-irradiated control group (1.47-1.95-folds of control). These results suggested that the CA and CC extracts and their isolated compounds could prevent UVB-inhibited human keratinocyte cells proliferation.

To investigate the effects of the CA and CC extracts and their isolated compounds 1-4 on the level of MMP-1 in UVB-irradiated human HaCaT keratinocytes cells, the cells were pre-treated with the tested samples for $24 \mathrm{~h}$ before repeated UVB irradiation $\left(100 \mathrm{~mJ} / \mathrm{cm}^{2} \times 10\right.$ times) (Figure 8$)$. The amount of MMP-1 secreted into the culture medium was analyzed. The results showed that the level of MMP-1 secretion dramatically increased in repeatedly UVB-irradiated keratinocytes (control group) compared with non-irradiated keratinocytes (4.29-fold of non-UVB-irradiated cells), but treatment with $0.5 \mu \mathrm{g} / \mathrm{mL}$ of the CA extract markedly inhibited UV-induced MMP-1 (6.42-fold of control). Furthermore, the $1.0 \mu \mathrm{g} / \mathrm{mL}$ of CC extract decreased the level of MMP-1 (4.31-fold of control) (Figure 8). Pre-treatment with the CA and CC extracts and their isolated compounds 1-4 after UVB irradiation decreased the level of MMP-1 produced by keratinocytes compared with the UVB-irradiated group (8.68 to 18.18-folds of control) (Figure 8). Thus, it could be concluded that compounds 1-4 play a critical role in human keratinocytes by preventing the UVB-induced overexpression of MMP-1. Our study on human keratinocyte cells demonstrated that MMP-1 expression was activated in UVB-irradiated HaCaT cells and a significant reduction in MMP-1 expression in cells pre-treated with the CA and CC extracts and their constituents were observed. Therefore, the prevention of UVB-induced skin damage caused by collagen breakdown could be, at least in the past, attributed to a reduction in the overexpression of MMP-1. In addition, our finding is consistent with 
other reports demonstrating that (-)-xanthorrhizol (2), isolated from Curcuma xanthorrhiza, significantly reduced MMP-1 expression in a dose-dependent manner [43], while germacrone (3), also isolated from the same plant species, inhibited protein expression levels of MMP-1, MMP-2, and MMP-3 in human keratinocytes and UVB-induced upregulation of the mRNA [44]. However, the molecular mechanism by which the CA and CC extracts reduce MMP-1 expression requires further study.

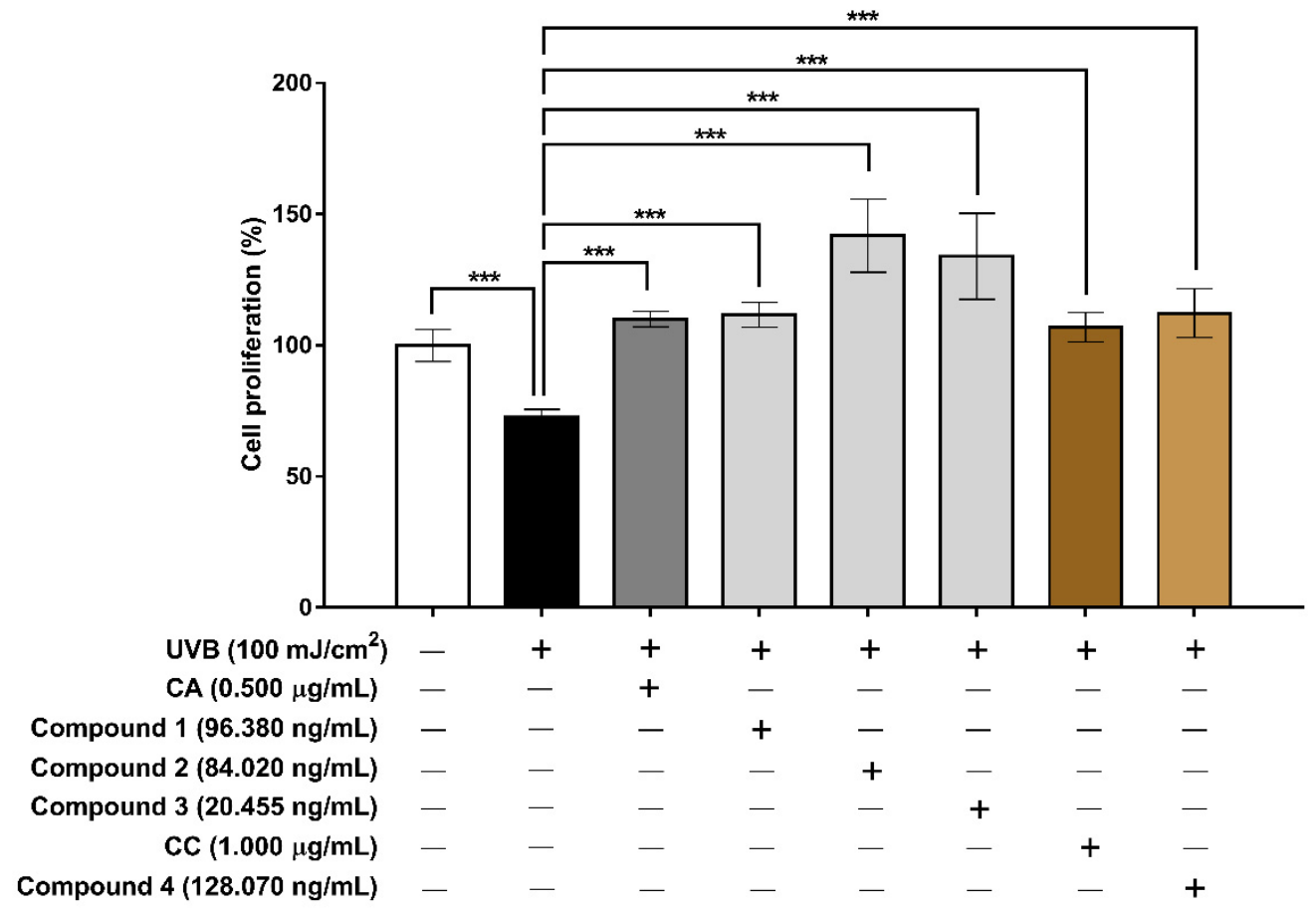

Figure 7. Effects of the CA and CC extracts and isolated constituents on cell proliferation by UVBinduction. Human skin keratinocytes were pre-treated with the tested samples for $24 \mathrm{~h}$ before repeated UVB irradiation $\left(100 \mathrm{~mJ} / \mathrm{cm}^{2} \times 10\right.$ times). Cells were harvested for $24 \mathrm{~h}$ after the tenth of UVB irradiation. The percentage of cell proliferation was determined via the trypan blue assay. Data are presented as the means $\pm \mathrm{SD}$. ${ }^{* * *} p<0.05$, using unpaired Student's $t$-test.

\subsection{Cell Cycle Arrest of UVB-Exposed Cells to the Extracts and Isolated Constituents}

Cell cycle arrest is one of the most typical events that occur during cell development, which consists of four stages including G1, S, G2, and M phases. The synthesis of enzymes essential for DNA replication is a hallmark of the G1 phase. DNA is duplicated during the $S$ phase to form two identical sets of chromosomes. The G2 phase is primarily concerned with the creation of microtubules, which are necessary during the mitotic phase of cell division. During the interphase, there is an increase in cell volume (G1, S, and G2 phases). The parent cell is divided into two daughter cells by nuclear and cytoplasmic divisions and the production of a new cell membrane during the $\mathrm{M}$ phase, which sequentially includes prophase, metaphase, anaphase, and telophase. The G1/S transition is one of the two key checkpoints in the cell cycle, with the other occurring at the G2/M transition. It controls the cell cycle and is responsible for the initiation and completion of DNA replication. DNA ploidy and protein analyses are commonly used in cell cycle studies after fluorescent staining or labeled nucleic acid incorporation. The cell-cycle reagent contains the dye propidium iodide (PI), which could penetrate cell membranes, bind covalently to DNA, and emit red fluorescence [45-48]. 


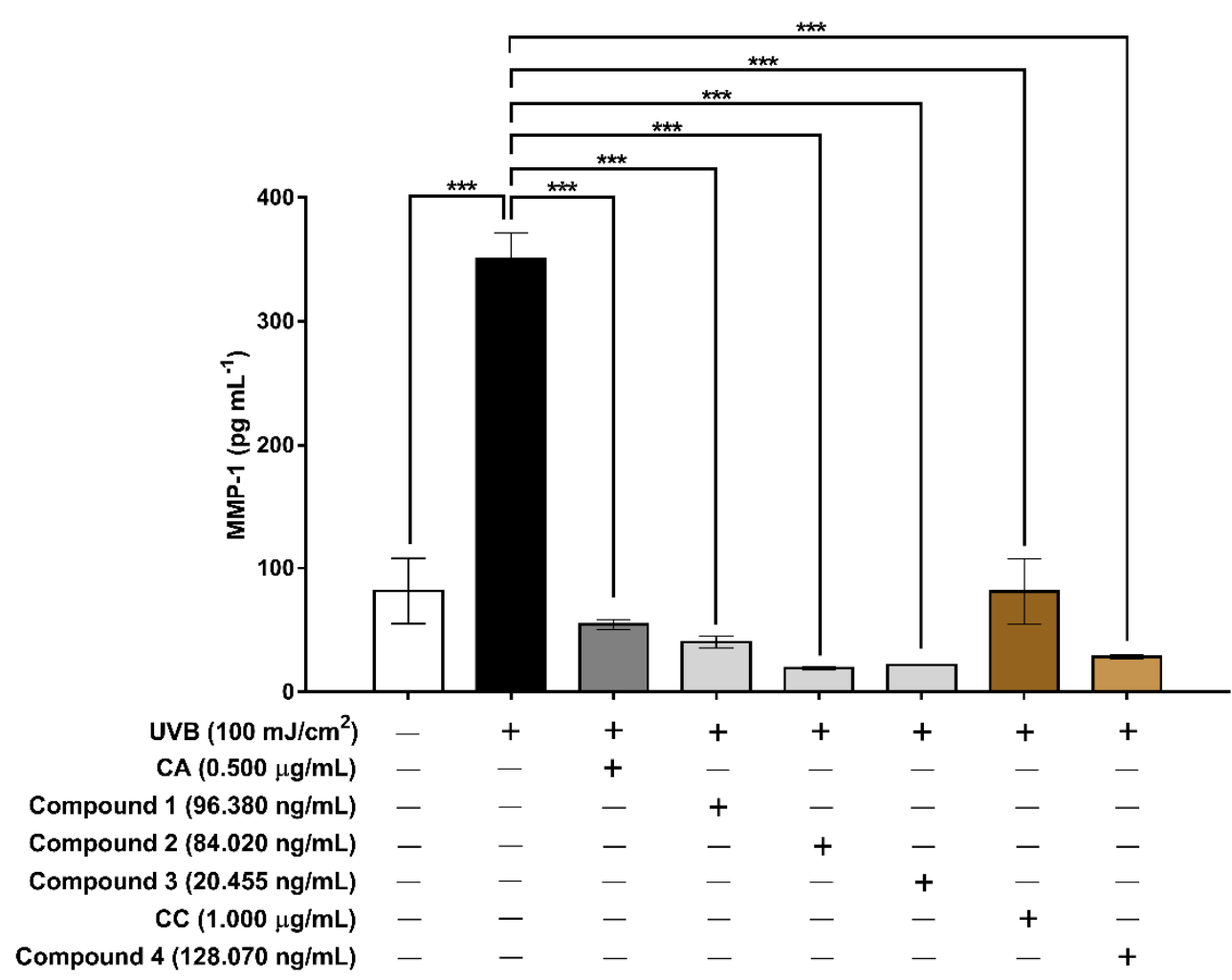

Figure 8. Effects of the CA and CC extracts and isolated constituents on MMP-1 production by UVB-induction. Human skin keratinocytes were pre-treated with the tested samples for $24 \mathrm{~h}$ before repeated UVB irradiation $\left(100 \mathrm{~mJ} / \mathrm{cm}^{2} \times 10\right.$ times). Cell-free supernatants were collected for ELISA for $24 \mathrm{~h}$ after the tenth irradiation. Data are presented as the means $\pm \mathrm{SD}$. ${ }^{* *} p<0.05$, using unpaired Student's $t$-test.

To investigate the possibility that the cell cycle was suppressed by the CA and CC extracts and their constituents 1-4, results from cell cycle disruption, flow cytometric analyses stained with PI were performed. Cell cycle progression was examined after $24 \mathrm{~h}$ of the tenth of $100 \mathrm{~mJ} / \mathrm{cm}^{2} \mathrm{UVB}$ irradiation of human HaCaT keratinocytes treated with the CA and CC extracts and isolated compounds 1-4. The histograms generated were analyzed with InCyte Software for Guava easyCyte HT Systems, to determine the proportion of cells in G0/G1, S, and G2/M for each sample. The gating histogram and cell cycle distribution of cell cycle were illustrated in Figure 9A,B. Table 3 presents the percentages of cells in the cell cycle phases (G0/G1, S, and G2/M). The results revealed that repeated UVB exposure induces an increase in the percentages of cells in the G0/G1 and $S$ phases. On the other hand, the repeated UVB exposure exhibited a decrease in the percentages of cells in the G2/M phase at $24 \mathrm{~h}$ post-UVB irradiation. Interestingly, pre-treatment of UVB-exposed cells to the CA and CC extracts resulted in a decrease of cell populations compared with the UVB-treated control group in the G0/G1 phase $(-2.7 \%$ and $-1.2 \%$ at $24 \mathrm{~h}$ after the last UVB irradiation, respectively) and the $S$ phase $(-2.8 \%$ and $-2.6 \%$, respectively), associated with increases of cells in the $\mathrm{G} 2 / \mathrm{M}$ phase $(+5.6 \%$ and $+3.8 \%$, respectively). In addition, the percentages of the sub-G1 phase were less than $0.2 \%$ (data not shown) the same as the non-UVB-treated group, since both extracts did not induce cell death at the tested concentration. Furthermore, the isolated constituents of both extracts also showed the percentages of cell populations in G0/G1, S, and G2/M in a similar trend with their extracts. It seemed probable that compounds 1-4 play an important protective role in the CA and CC extracts against UVB-induced cell growth inhibition. As in other investigations, UVB has been used to perform cell cycle arrest [49]. In this study, the cell populations in the G0/1 and S phases were significantly increased after UVB irradiation, indicating cells were arrested at the G0/G1 and S phases. Our results imply that the CA and 
CC extracts, and their isolated constituents 1-4 restored cell cycle arrest to levels similar to those of the non-UVB irradiated group at low concentrations after $24 \mathrm{~h}$ of UVB irradiation, indicating that the CA and CC extracts and their constituents could rescue UVB-induced cell cycle arrest. Consequently, their treatment at the tested concentrations did not induce cell death in HaCaT cells. Therefore, the CA and CC extracts along with their constituents showed a photoprotective effect against UVB-induced cell growth inhibition. However, the mechanism of its action is required.

A
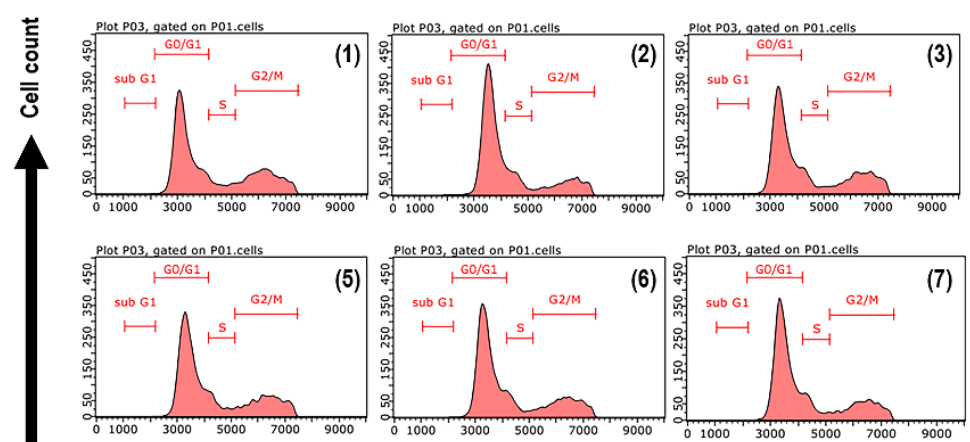

7)

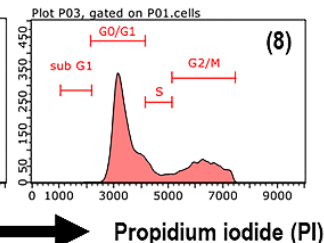

B

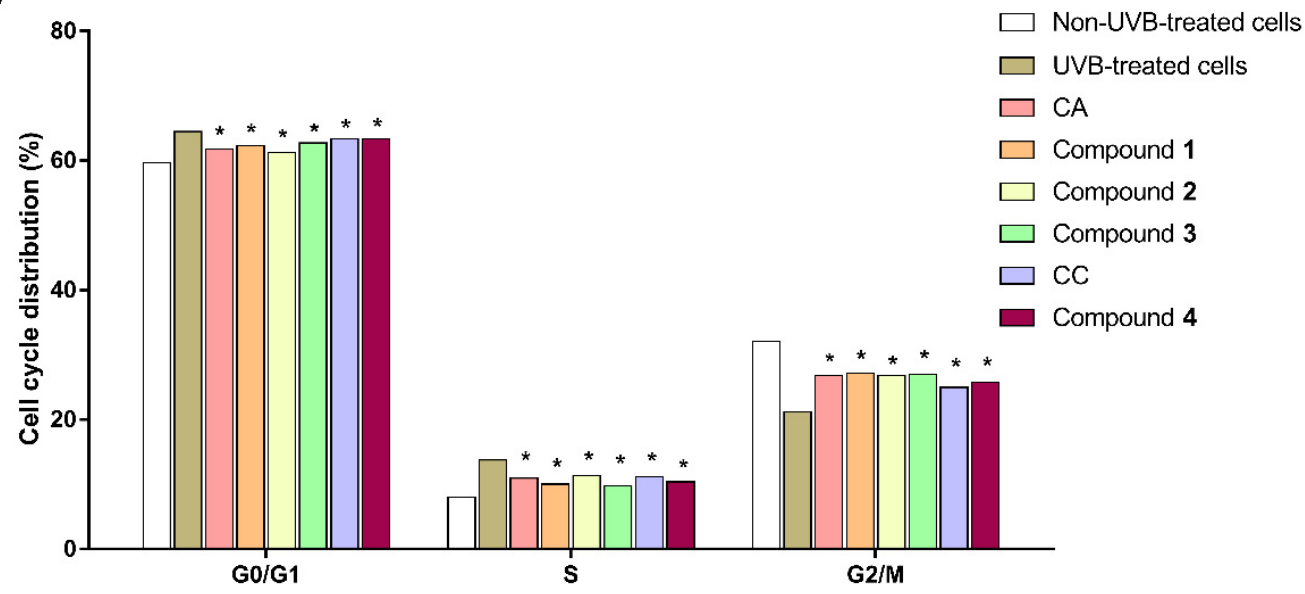

Figure 9. Cell cycle arrested following CA and CC extracts and isolated compounds treatments for 48 h. $0.1 \%$ DMSO was used as a control. The cell cycle was analyzed using flow cytometry. Human keratinocytes were pre-treated with the tested samples for $24 \mathrm{~h}$. The cells were harvested, stained with propidium iodide (PI) for $24 \mathrm{~h}$ after the tenth UVB irradiation $\left(100 \mathrm{~mJ} \mathrm{~cm}^{-2}\right)$ and DNA content was quantified by flow cytometry. (A) Data shows the gating histogram showing the percentage of cells in the G0/G1, S and G2/M phases of the cell cycle obtained after flow cytometry analysis, where (1) = non-UVB-treated cells, (2) = UVB-treated cells, (3) = CA extract, (4) = compound 1, $(5)=$ compound $2,(6)=$ compound $3,(7)=$ CC extract and $(8)=$ compound 4 . For each sample, 500,000 cells were acquired. (B) Cell cycle distribution pre-treated compounds treatments. Data are presented as the means \pm SD. Asterisks $\left(^{*}\right)$ denote significant differences from the UVB-treated group $(p<0.05)$. 
Table 3. Cell cycle distribution of the CA and CC extracts and isolated compounds 1-4 treated HaCaT cells at $24 \mathrm{~h}$ after the tenth UVB exposure $\left(100 \mathrm{~mJ} / \mathrm{cm}^{2}\right)$.

\begin{tabular}{cccc}
\hline Sample & \multicolumn{2}{c}{ \% of Total Cell Cycle Population in: } \\
\cline { 2 - 4 } & G0/G1 & S & G2/M \\
\hline Non-UVB-treated cells & $59.64 \pm 2.01$ & $7.96 \pm 0.05$ & $32.05 \pm 2.09$ \\
UVB-treated cells & $64.47 \pm 0.79$ & $13.73 \pm 0.11$ & $21.17 \pm 0.81$ \\
CA extract & $61.73 \pm 1.24$ & $10.93 \pm 1.28$ & $26.77 \pm 2.52$ \\
Compound 1 & $62.28 \pm 0.42$ & $10.03 \pm 0.54$ & $27.15 \pm 0.81$ \\
Compound 2 & $61.25 \pm 0.54$ & $11.34 \pm 1.17$ & $26.83 \pm 1.29$ \\
Compound 3 & $62.69 \pm 0.86$ & $9.76 \pm 0.10$ & $26.95 \pm 0.96$ \\
CC extract & $63.31 \pm 0.37$ & $11.15 \pm 0.56$ & $24.98 \pm 0.22$ \\
Compound 4 & $63.35 \pm 0.19$ & $10.40 \pm 1.29$ & $25.74 \pm 2.53$ \\
\hline
\end{tabular}

The results were expressed as mean \pm standard deviation (SD) of triplicate experiments. $(n=3)$.

\section{Conclusions}

In conclusion, we demonstrated that C. aromatica and C. comosa extracts, and their isolated constituents had photoprotective effects against UVB-induced HaCaT keratinocyte cells, which did not induce cell death. They increased cell proliferation, inhibited MMP-1 overexpression and restore cell cycle arrest in UVB-irradiated HaCaTs. C. aromatica and C. comosa extracts and their isolated constituents may serve as potential candidates for the prevention of skin photoaging. However, further studies are necessary to elucidate the signaling pathways and molecular mechanisms involved in the anti-photoaging activity of these agents.

Author Contributions: Conceptualization, W.N.; methodology, W.N.; software, W.P.; validation, W.N. and W.P.; formal analysis, W.P. and W.N.; investigation, W.P., W.N., W.C., N.P. and S.P.; resources, W.N., A.S. and B.-e.Y.; data curation, W.P., W.N., W.C. and A.S.; writing-original draft preparation, W.P.; writing-review and editing, W.N., A.S., J.V., V.A., W.C., N.P. and S.P.; visualization, W.P.; supervision, A.S., J.V., B.-e.Y., V.A., A.C. and P.P.; project administration, W.N.; funding acquisition, A.S. and W.N. All authors have read and agreed to the published version of the manuscript.

Funding: This research was funded by the Agricultural Research Development Agency (Public Organization), grant number CRP6305030500 and The Thailand Research Fund, grant number DBG6180030.

Institutional Review Board Statement: Not applicable.

Informed Consent Statement: Not applicable.

Data Availability Statement: Not applicable.

Acknowledgments: This work was supported by the Agricultural Research Development Agency (Public Organization) (grant number CRP6305030500). W.P. thanks the scholarship from the Science Achievement Scholarship of Thailand, Ministry of Higher Education, Science, Research and Innovation. Partial supports from Ramkhamhaeng University, The Thailand Research Fund (grant number DBG6180030) and the Center of Excellence for Innovation in Chemistry (PERCH-CIC), Ministry of Higher Education, Science, Research and Innovation are also gratefully acknowledged.

Conflicts of Interest: The authors declare no conflict of interest.

\section{References}

1. Ganceviciene, R.; Liakou, A.I.; Theodoridis, A.; Makrantonaki, E.; Zouboulis, C.C. Skin anti-aging strategies. Dermatoendocrinology 2012, 4, 308-319. [CrossRef] [PubMed]

2. Cevenini, E.; Invidia, L.; Lescai, F.; Salvioli, S.; Tieri, P.; Castellani, G.; Franceschi, C. Human models of aging and longevity. Expert Opin. Biol. Ther. 2008, 8, 1393-1405. [CrossRef] [PubMed]

3. Farage, M.A.; Miller, K.W.; Elsner, P.; Maibach, H.I. Intrinsic and extrinsic factors in skin ageing: A review. Int. J. Cosmet. Sci. 2008, 30, 87-95. [CrossRef] [PubMed] 
4. $\quad$ Song, J.H.; Piao, M.J.; Han, X.; Kang, K.A.; Kang, H.K.; Yoon, W.J.; Ko, M.H.; Lee, N.H.; Lee, M.Y.; Chae, S.; et al. Anti-wrinkle effects of Sargassum muticum ethyl acetate fraction on ultraviolet B-irradiated hairless mouse skin and mechanistic evaluation in the human HaCaT keratinocyte cell line. Mol. Med. Rep. 2016, 14, 2937-2944. [CrossRef]

5. Krutmann, J.; Bouloc, A.; Sore, G.; Bernard, B.A.; Passeron, T. The skin aging exposome. J. Dermatol. Sci. 2017, 85, 152-161. [CrossRef]

6. Pambianchi, E.; Hagenberg, Z.; Pecorelli, A.; Grace, M.; Therrien, J.-P.; Lila, M.A.; Valacchi, G. Alaskan bog blueberry (Vaccinium uliginosum) extract as an innovative topical approach to prevent UV-induced skin damage. Cosmetics 2021, 8, 112. [CrossRef]

7. Morocho-Jácome, A.L.; Freire, T.B.; de Oliveira, A.C.; de Almeida, T.S.; Rosado, C.; Velasco, M.V.R.; Baby, A.R. In vivo SPF from multifunctional sunscreen systems developed with natural compounds-A review. J. Cosmet. Dermatol. 2021, 20, 729-737. [CrossRef]

8. Kwon, K.-R.; Alam, M.B.; Park, J.-H.; Kim, T.-H.; Lee, S.-H. Attenuation of UVB-induced photo-aging by polyphenolic-rich Spatholobus suberectus stem extract via modulation of MAPK/AP-1/MMPs signaling in human keratinocytes. Nutrients 2019, 11, 1341. [CrossRef]

9. Verma, R.P.; Hansch, C. Matrix metalloproteinases (MMPs): Chemical-biological functions and (Q)SARs. Bioorg. Med. Chem. 2007, 15, 2223-2268. [CrossRef]

10. Jabłońska-Trypuć, A.; Matejczyk, M.; Rosochacki, S. Matrix metalloproteinases (MMPs), the main extracellular matrix (ECM) enzymes in collagen degradation, as a target for anticancer drugs. J. Enzyme Inhib. Med. Chem. 2016, 31, 177-183. [CrossRef]

11. Dong, K.K.; Damaghi, N.; Picart, S.D.; Markova, N.G.; Obayashi, K.; Okano, Y.; Masaki, H.; Grether-Beck, S.; Krutmann, J.; Smiles, K.A.; et al. UV-induced DNA damage initiates release of MMP-1 in human skin. Exp. Dermatol. 2008, 17, 1037-1044. [CrossRef]

12. Kim, C.; Ryu, H.C.; Kim, J.H. Low-dose UVB irradiation stimulates matrix metalloproteinase-1 expression via a BLT2-linked pathway in HaCaT cells. Exp. Mol. Med. 2010, 42, 833-841. [CrossRef] [PubMed]

13. Ryu, J.Y.; Na, E.J. MMP expression alteration and MMP-1 production control by syringic acid via AP-1 mechanism. Biomed. Dermatol. 2018, 2, 15. [CrossRef]

14. Pittayapruek, P.; Meephansan, J.; Prapapan, O.; Komine, M.; Ohtsuki, M. Role of matrix metalloproteinases in photoaging and photocarcinogenesis. Int. J. Mol. Sci. 2016, 17, 868. [CrossRef] [PubMed]

15. Kuroyanagi, M.; Ueno, A.; Ujiie, K.; Sato, S. Structures of sesquiterpenes from Curcuma aromatica Salisb. Chem. Pharm. Bull. 1987, 35, 53-59. [CrossRef]

16. Al-Reza, S.M.; Rahman, A.; Sattar, M.A.; Rahman, M.O.; Fida, H.M. Essential oil composition and antioxidant activities of Curcuma aromatica Salisb. Food Chem. Toxicol. 2010, 48, 1757-1760. [CrossRef]

17. Ahmed, S.; Ansari, S.H.; Ali, M.; Bhatt, D.; Ansari, F. Phytochemical and biological investigations on Curcuma aromatica. Pharmacog. Rev. 2008, 2, 151-156.

18. Pintatum, A.; Maneerat, W.; Logie, E.; Tuenter, E.; Sakavitsi, M.E.; Pieters, L.; Berghe, W.V.; Sripisut, T.; Deachathai, S.; Laphookhieo, S. In vitro anti-inflammatory, antioxidant, and cytotoxic activities of four Curcuma species and the isolation of compounds from Curcuma aromatica rhizome. Biomolecules 2020, 10, 799. [CrossRef]

19. Sun, W.; Wang, S.; Zhao, W.; Wu, C.; Guo, S.; Gao, H.; Tao, H.; Lu, J.; Wang, Y.; Chen, X. Chemical constituents and biological research on plants in the genus Curcuma. Crit. Rev. Food Sci. Nutr. 2016, 57, 1451-1523. [CrossRef]

20. Soontornchainaksaeng, P.; Jenjittikul, T. Chromosome number variation of phytoestrogen-producing Curcuma (Zingiberaceae) from Thailand. J. Nat. Med. 2010, 64, 370-377. [CrossRef]

21. Piyachaturawat, P.; Ercharuporn, S.; Suksamrarn, A. Uterotrophic effect of Curcuma comosa in rats. Int. J. Pharmacogn. 1995, 33, 334-338. [CrossRef]

22. Piyachaturawat, P.; Ercharuporn, S.; Suksamrarn, A. Estrogenic activity of Curcuma comosa extract in rats. Asia Pac. J. Pharmacol. 1995, 10, 121-126.

23. Winuthayanon, W.; Piyachaturawat, P.; Suksamrarn, A.; Ponglikitmongkol, M.; Arao, Y.; Hewitt, S.C.; Korach, K.S. Diarylheptanoid phytoestrogens isolated from the medicinal plant Curcuma comosa: Biological actions in vitro and in vivo indicate estrogen receptor-dependent mechanisms. Environ. Health Persp. 2009, 117, 1155-1161. [CrossRef] [PubMed]

24. Suksamrarn, A.; Ponglikitmongkol, M.; Wongkrajang, K.; Chindaduang, A.; Kittidanairak, S.; Jankam, A.; Yingyongnarongkul, B.; Kittipanumat, N.; Chokchaisiri, R.; Khetkam, P.; et al. Diarylheptanoids, new phytoestrogens from the rhizomes of Curcuma comosa: Isolation, chemical modification and estrogenic activity evaluation. Bioorg. Med. Chem. 2008, 16, 6891-6902. [CrossRef]

25. Piyachaturawat, P.; Charoenpiboonsin, J.; Toskulkao, C.; Suksamrarn, A. Reduction of plasma cholesterol by Curcuma comosa extract in hypercholesterolaemic hamsters. J. Ethnopharmacol. 1999, 66, 199-204. [CrossRef]

26. Sutjarit, N.; Sueajai, J.; Boonmuen, N.; Sornkaew, N.; Suksamrarn, A.; Tuchinda, P.; Zhu, W.; Weerachayaphorn, J.; Piyachaturawat, P. Curcuma comosa reduces visceral adipose tissue and improves dyslipidemia in ovariectomized rats. J. Ethnopharmacol. 2017, 215, 167-175. [CrossRef]

27. Tantikanlayaporn, D.; Wichit, P.; Weerachayaphorn, J.; Chairoungdua, A.; Chuncharunee, A.; Suksamrarn, A.; Piyachaturawat, P. Bone sparing effect of a novel phytoestrogen diarylheptanoid from Curcuma comosa Roxb. in ovariectomized rats. PLoS ONE 2013, 8, e78739. [CrossRef] 
28. Tanhuad, N.; Thongsa-Ad, U.; Sutjarit, N.; Yoosabai, P.; Panvongsa, W.; Wongniam, S.; Suksamrarn, A.; Piyachaturawat, P.; Anurath-apan, U.; Borwornpinyo, S.; et al. Ex vivo expansion and functional activity preservation of adult hematopoietic stem cells by a diarylheptanoid from Curcuma comosa. Biomed. Pharm. 2021, 143, 112102. [CrossRef]

29. Chuaicharoen, P.; Charaslertrangsi, T.; Chuncharunee, A.; Suksamrarn, A.; Piyachaturawat, P. Non-phenolic diarylheptanoid from Curcuma comosa protects against thioacetamide-induced acute hepatotoxicity in mice. Pharm. Sci. Asia 2020, $47,74-85$. [CrossRef]

30. Jantaratnotai, N.; Utaisincharoen, P.; Piyachaturawat, P.; Chongthammakun, S.; Sanvarinda, Y. Inhibitory effect of Curcuma comosa on NO production and cytokine expression in LPS-activated microglia. Life Sci. 2006, 78, 571-577. [CrossRef]

31. Sodsai, A.; Piyachaturawat, P.; Sophasan, A.; Suksamrarn, A.; Vongsakul, M. Suppression by Curcuma comosa Roxb. of proinflammatory cytokine secretion in phorbol-12-myristate-13-acetate stimulated human mononuclear cells. Int. Immunopharmacol. 2007, 7, 524-531. [CrossRef] [PubMed]

32. Nakyai, W.; Pabuprapap, W.; Sroimee, W.; Ajavakom, V.; Yingyongnarongkul, B.; Suksamrarn, A. Anti-acne vulgaris potential of the ethanolic extract of Mesua ferrea L. flowers. Cosmetics 2021, 8, 107. [CrossRef]

33. Ehara, T.; Tanikawa, S.; Ono, M.; Akita, H. Synthesis of $(R)$-curcumene and $(R)$-xanthorrizol based on 1,2-aryl migration via phenonium ion. Chem. Pharm. Bull. 2007, 55, 1361-1364. [CrossRef] [PubMed]

34. Chavan, S.P.; Thakkar, M.; Kalkote, U.R. An enantiospecific synthesis of (+)-isoparvifolinone and (-)-parvifoline. Tetrahedron Lett. 2007, 48, 535-537. [CrossRef]

35. Barrero, A.F.; Herrador, M.M.; López-Pérez, J.-L.; Arteaga, J.F.; Catalán, J. New pathways in transannular cyclization of germacrone [germacra-1(10),4,7(11)-trien-8-one]: Evidence regarding a concerted mechanism. Org. Lett. 2009, 11, 4782-4785. [CrossRef]

36. Demirci-Çekiça, S.; Özkan, G.; Avan, A.N.; Uzunboy, S.; Çapanoğlu, E.; Apak, R. Biomarkers of oxidative stress and antioxidant defense. J. Pharm. Biomed. Anal. 2022, 209, 114477. [CrossRef]

37. Tiraravesit, N.; Yakaew, S.; Rukchay, R.; Luangbudnark, W.; Viennet, C.; Humbert, P.; Viyoch, J. Artocarpus altilis heartwood extract protects skin against UVB in vitro and in vivo. J. Ethnopharmacol. 2015, 175, 153-162. [CrossRef]

38. Kwon, S.H.; Wang, Z.; Hwang, S.H.; Kang, Y.-H.; Lee, J.-Y.; Lim, S.S. Comprehensive evaluation of the antioxidant capacity of Perilla frutescens leaves extract and isolation of free radical scavengers using step-wise HSCCC guided by DPPH-HPLC. Int. J. Food Prop. 2017, 20, 921-934. [CrossRef]

39. Apak, R.; Özyürek, M.; Güçlü, K.; Çapanoğlu, E. Antioxidant activity/capacity measurement. 1. classification, physicochemical principles, mechanisms, and electron transfer (ET)-based assays. J. Agric. Food Chem. 2016, 64, 997-1027. [CrossRef]

40. Kuntasal, O.O.; Karman, D.; Wang, D.; Tuncel, S.G.; Tuncel, G. Determination of volatile organic compounds in different microenvironments by multibed adsorption and short-path thermal desorption followed by gas chromatographic-mass spectrometric analysis. J. Chromatogr. A 2005, 1099, 43-54. [CrossRef]

41. Huber, L. Validation and Qualification in Analytical Laboratories, 2nd ed.; Informa Healthcare USA, Inc.: New York, NY, USA, 2007; pp. 125-154.

42. Behzadi, M.A.; Choi, A.; Duehr, J.; Feyznezhad, R.; Upadhyay, C.; Schotsaert, M.; Palese, P.; Nachbagauer, R. A cross-reactive mouse monoclonal antibody against rhinovirus mediates phagocytosis in vitro. Sci. Rep. 2020, 10, 9750. [CrossRef] [PubMed]

43. Oh, H.-I.; Shim, J.-S.; Gwon, S.-H.; Kwon, H.-J.; Hwang, J.-K. The effect of xanthorrhizol on the expression of matrix metalloproteinase-1 and type-I procollagen in ultraviolet-irradiated human skin fibroblasts. Phytother. Res. 2009, 23, 1299-1302. [CrossRef] [PubMed]

44. Park, J.-H.; Mohamed, M.A.A.; Jung, Y.-J.; Shrestha, S.; Lee, T.H.; Lee, C.-H.; Han, D.; Kim, J.; Baek, N.-I. Germacrane sesquiterpenes isolated from the rhizome of Curcuma xanthorrhiza Roxb. inhibit UVB-induced upregulation of MMP-1, -2, and -3 expression in human keratinocytes. Arch. Pharm. Res. 2014, 38, 1752-1760. [CrossRef] [PubMed]

45. Zhang, C.; Zhang, J.; Li, X.; Sun, N.; Yu, R.; Zhao, B.; Yu, D.; Cheng, Y.; Liu, Y. Huaier aqueous extract induces hepatocellular carcinoma cells arrest in S phase via JNK signaling pathway. Evid. Based Complement. Altern. Med. 2015, 171356, 1-11. [CrossRef] [PubMed]

46. Xu, N.; Chen, X.; Rui, J.; Yu, Y.; Gu, D.; Ruan, J.J.; Ruan, B.H. Cell growth measurement. In Cell Growth; IntechOpen: London, UK, 2020. [CrossRef]

47. Tiraravesit, N.; Humbert, P.; Robin, S.; Tissot, M.; Viennet, C.; Viyoch, J. Artocarpin-enriched (Artocarpus altilis) heartwood extract provides protection against UVB-induced mechanical damage in dermal fibroblasts. Photochem. Photobiol. 2017, 93, 1232-1239. [CrossRef]

48. Nakyai, W.; Saraphanchotiwitthaya, A.; Viennet, C.; Humbert, P.; Viyoch, J. An in vitro model for fibroblast photoaging comparing single and repeated UVA irradiations. Photochem. Photobiol. 2017, 93, 1462-1471. [CrossRef]

49. Deng, M.; Li, D.; Zhang, Y.; Zhou, G.; Liu, W.; Cao, Y.; Zhang, W. Protective effect of crocin on ultraviolet B-induced dermal fibroblast photoaging. Mol. Med. Rep. 2018, 18, 1439-1446. [CrossRef] 